\author{
Ks. Stanisław LONGOSZ \\ (Lublin, KUL)
}

\title{
RECEPCJA SWIETEGO AUGUSTYNA W KULTURZE POLSKIEJ
}

Nie jest łatwo ocenić znajomość danego autora w jakiejś społeczności. Wydaje się jednak, że pewnym obiektywnym śladem takiej znajomóści są wydania jego dzieł w oryginale lub przekładach, oraz rozprawy, książki i artykuły opublikowane na jego temat, a przede wszystkim recepcja głoszonych przez niego idei - chodzi tu więc głównie o pełną bibliografie tej społeczności na jego tcmat. Otóż jeżeli chodzi o św. Augustyna, którego 1650 rocznicę urodzin w tym roku obchodzimy, to nie wydano w Polsce dotąd żadnego jego dziela krytycznie, nie przetłumaczono na język polski wszystkich jego dzieł i nie sporządzono dotąd pełnej jego bibliografii, jeśli zaś chodzi o recepcję jego idei w kulturze polskiej, to jak się wydaje, nie bylo jej u nas w postaci liczącej się w świecie. Gdy zaś chodzi o ogólną znajomość św. Augustyna w Polsce, to sytuacja nie przedstawia się najgorzej, o czym świadczą, również pomniki materialne, jak dedykowanych mu 13 kościołów oraz jego ikonografia - poświęcone mu rzeźby i obrazy; $z$ nimi wiąże się jego kult - poświęcone mu polskie pieśni, fundacje i stowarzyszenia jego imienia, a także związane z nim przysłowia, zwyczaje i imprezy publiczne.

Św. Augustyn jest bez wątpienia autorem, który ze wszystkich pisarzy wczesnochrześcijańskich był w kulturze europejskiej i polskiej najczęściej cytowany, przywolywany i studiowany. Publikowana w tym roku z okazji 1650 rocznicy jego urodzin w 44-45 tomie „Vox Patrum” jego licząca ponad 120 stron bibliografia $S w$. Augustyn w polskich studiach. Materiaty bibliograficz$n e^{1}$, wymienia 64-tytuly całych przetłumaczonych pism św. Augustyna na 109 tytułów wymienionych w Clavis Patrum Latinorum (nr 251-357, 1838-1839ab) oraz 5 tytułów pism pseudoaugustyńskich, jak np. Kazanie o świętokradztwie (CPL 1163a), Kazanie o narodzinach Jana Chrzciciela (CPPM 1651), czy też

\footnotetext{
${ }^{1}$ Por. „Vox Patrum” 23 (2003) t. 44-45, 521-624.
} 
Kazanie o Ewangelii, w której Pan uczynit niebo z wina (CPPM 1220), należących do literatury średniowiecznej; na język polski mamy w sumie przetłumaczone dopiero ok. $60 \%$ jego pism.

Naliczyliśmy ponadto blisko 1000 (ponad 980) dhuższych lub krótszych fragmentów pism św. Augustyna, cytowanych w różnych antologiach, zbiorach lub okolicznościach, jak np. w tomach Ojców Żywych, Rozmowach ze św. Augustynem o. Jacka Salija, czy Liturgii Godzin. Można zauważyć, że najwięcej tego rodzaju fragmentów pochodzi z jego: Objaśnień Psalmów (ponad 170), Homilii na Ewangelię św. Jana (ponad 130), Wyznań (ponad 70), O państwie Bożym (ponad 50), O Trójcy Świętej (ponad 25) oraz Listów, zwłaszcza 130 listu do Proby (ponad 15). Ilość tych cytowań daje pewien przybliżony obraz obecności i aktualności myśli augustyńskiej w naszej kulturze.

Jeśli natomiast chodzi o polskie przekłady pism św. Augustyna, to są w zasadzie przetłumaczone główne jego dzieła, a niektóre nawet kilkakrotnie. A więc: Wyznania - pięciokrotnie:

P. Pękalski - Kraków 1847

M. Bohusz Szyszko - Wilno 1844, 1903, 1912, 1914, 1920, 1923

J. Czuj - Poznań 1929, POK 9; Kraków 1949 (nowe i poprawione); Warszawa PAX 1954, 1955.

K. Wisłocka-Remerowa ks. I-X - Kraków 1929

Z. Kubiak - Warszawa PAX 1978, 1982, 1984, 1987, 1992; Kraków ZNAK 1997, 1999

O Państwie Bożym - trzykrotnie:

M. Gladyszewicz, O mieście Bożym I-V, Kraków 1835

W. Kubicki - Poznań 1930, 1934, 1937, POK 11-13, wznowione: Kęty 1998, Wydaw. ANTYK

W. Kornatowski - Warszawa PAX 1977, 2003 PAX - ALTAYA

Wielkie zasługi wobec św. Augustyna ma p. Jan Sulowski, któremu zawdzięczamy kilkanaście przetłumaczonych tomów w serii PSP, a mianowicie:

Warszawa 1979, PSP 22 (O nauce chrześcijańskiej, Sprostowania),

Warszawa 1980, PSP 25 (Przeciwko manichejczykom komentarz do Księgi Rodzaju, Niedokończony komentarz stowny do Księgi Rodzaju, Komentarz stowny do Księgi Rodzaju),

Warszawa 1986, PSP 37-42 (Objaśnienia Psalmów),

Warszawa 1990, PSP 46-47 (Problemy Heptateuchu: Do Księgi Rodzaju, Wyjścia, Kaplańskiej, Liczb, Powtórzonego Prawa, Jozuego, Sędziów; Sposoby mówienia Heptateuchu, Osiem problemów ze Starego Testamentu),

Warszawa 1990, PSP 48 (O kazaniu Pańskim na górze, Do Symplicjana o róznych problemach, Problemy ewangeliczne),

Warszawa 1990, PSP 50 (O zgodności ewangelistów),

Warszawa 1990, PSP 54 (O pożytku wiary, $O$ dwóch duszach, Sprawozdanie $z$ dyskusji z Fortunatem, List podstawowy, Przeciw Adimantowi, Przeciw Feliksowi), 
Warszawa 1991, PSP 55-56 (Przeciw Faustusowi, Przeciw Sekundynowi). Kilka pism św. Augustyna przełożył również niedawno zmarły wybitny polski augustynolog ks. Wacław Eborowicz, któremu zawdzięczamy:

Poznań 1970, POK 27: Traktaty o tasce (Laska a wolna wola, Nagana a taska,

Przeznaczenie świętych, Dar wytrwania),

Warszawa 1977, PSP 19, z. 1-3 (Przeciw Julianowi, Duch a litera),

Pelplin 1991, Listy 1-75.

$\mathrm{Z}$ innych polskich współczesnych tłumaczy pism św. Augustyna należy wymienić: ks. J. Jaworskiego, Wybór mów św. Augustyna (Warszawa 1973, PSP 12); ks. W. Budzika, Pisma katechetyczne św. Augustyna (Poczatkowe nauczanie katechizmu, Mowa o Symbolu do katechumenów, Wiara nadzieja i mitość, Chrześcijańska walka, POK 10, Poznań 1929; PAX, Warszawa 1952); M. Stokowską, O Trójcy Świętej (Poznań 1963, POK 25); o. W. Szołdrskiego i ks. W. Kanię, Homilie na Ewangelię i I List św. Jana (Warszawa 1977, PSP 15 cz. 1-2), a także ks. A. Eckmanna, któremu ostatnio zawdzięczamy opracowanie i wydanie przygotowanych przez różnych thumaczy augustyńskich Pism o matzenstwie i dziewictwie (Lublin 2003: Wartości matżenstwa, $O$ świętym dziewictwie, $O$ doskonatym wdowienstwie, Cudzotożne matżenstwa, O powściqgliwości, Małzeństwo i pożądliwość I).

Jeśli zaś chodzi o listy, to na 269 autentycznych listów św. Augustyna na język polski mamy przełożonych przez różnych tłumaczy 106 (1-75, 81-82, 123, $133,150,165-167,172,186,189,195,200,202-202$ A, 207-208, 214-215A, 218, $228,243,247-250,258-259,262-263)$ oraz 2 (17 i 20$)$ z nowo odkrytych w $1981 \mathrm{r}$. przez J. Divjaka (CSEL 88), a inne w ponad 50 fragmentach.

Gdy natomiast chodzi o często i już wcześniej wykorzystywane w naszej homiletyce mowy św. Augustyna, to spośród 363 jego mów na język polski mamy przełożonych przez różnych autorów (zwłaszcza przez ks. W. Eborowicza i ks. J. Jaworskiego) zaledwie 98 (8, 13 Denis, 15-16, 20, 25 Guelferb., $28,34,43,52-53,56-59,62,65,70,76,79,84,100,104,111,115,121,137,153$, $176,182,184-198,200-201,203,211,215,218,218 \mathrm{C}, 221,227-228,229 \mathrm{E}, 231-$ $233,243,246,258-259,260 \mathrm{~A}, 261,263,267-268,272,274,280,286-288,295$, $300,302-305,307,311,315,320,321-322,328,336,340,340 \mathrm{~A}, 347,352$, 355, 356-358). Tak oto wygląda aktualny stan przekładów pism św. Augustyna na język polski.

\section{II}

Pismami jednak tego Wielkiego Doktora Kościoła zaczęto się interesować już u zarania tworzenia się kultury polskiej, choć trudno dokładnie ustalić, kiedy jego dzicła i w jakim stopniu zagościły na naszej ziemi. Można przypuszczać, że przywozili je ze sobą pierwsi misjonarze oraz pierwsi biskupi (Jordan, 
Unger, św. Wojciech), którzy byli benedyktynami zazwyczaj obytymi z pismami Ojców Kościoła, ale nie zachowały się żadne katalogi ksiąg sprowadzanych wówczas do Polski ${ }^{2}$. Pierwszy taki zachowany katalog, sporządzony w $1110 \mathrm{r}$. z okazji inwentaryzacji skarbca kapituły krakowskiej, obejmuje 30 pozycji książkowych, w tym 6 pism Ojców Kościoła (głównie Grzegorza Wielkiego), ale nie ma wśród nich żadnego dzieła św. Augustyna, poza jedną jego homilią umieszczoną w jednym kodeksie z 29 homiliami Grzegorza Wielkiego i Bedy Czcigodnego $^{3}$, co niewątpliwie wskazuje na benedyktyńskie pochodzenie tego księgozbioru. Drugi natomiast analogiczny krakowski katalog, sporządzony na przełomie XII i XIII wieku (dokładnie przed 1207 r.), zawierający 42 dzieła w 32 kodeksach, wymienia już wśród 13 tytułów patrystycznych 4 dzieła św. Augustyna (Excerpta Augustini et diversorum Patrum; Augustinus de verbis Domini „Qui dixit fratri suo, fatue”, sermo 55; Liber Augustini de libero arbitrio; Quaestiones Orosii ad Augustinum), które prawdopodobnie sprowadzil studiujący wcześniej w Paryżu biskup krakowski Iwo Odrowąż ${ }^{4}$. Byłby to więc pierwszy ślad istnienia dzieł św. Augustyna na ziemi polskiej. Trzeci wreszcie znajdujący się w bibliotece kapituły krakowskiej, pochodzący z przełomu XV i XVI wieku wykaz rękopisów, zawierający także nieliczne dzieła wydane drukiem, wymienia 244 pozycje, z których 30 wylicza 78 tytułów pism Ojców Kościoła: $8 \mathrm{z}$ nich to dzieła Ojców greckich, a 70 Ojców łacińskich, w tym głównie, bo aż 34 dzieła św. Augustyna, lub mu przypisywane ${ }^{5}$, co wskazywałoby na coraz większe upowszechnienie pism augustyńskich w Polsce, choć nie znamy katalogów innych bibliotek katedralnych.

Mamy pewne świadectwa, że pismami Ojców Kościola, w tym również św. Augustyna, interesowali się nie tylko duchowni, ale również arystokracja i królowie polscy. Tak np. Kazimierz Wielki (1333-1370) w swej bibliotece na zamku wawelskim posiadał augustyński Komentarz do Ewangelii św. Jana, w bogatej oprawie ozdobionej monogramem królewskim, które to dzieło jest

${ }^{2}$ Por. Cz. Mazur, Początki znajomości pism św. Augustyna w Polsce, „Życie Katolickie” 7 (1988) nr 9, 54-57: G. Potarzyŕski, O recepcji św. Augustyna w Polsce, tamże, 5 (1986) nr 11-12, $69-$ 73; W. Eborowicz, Badania nad św. Augustynem w Polsce od 1918 roku, tamże, 7 (1988) nr 9, 58-70; J. Sulowski, Sw. Alıgustyn w Polsce. Polska bibliografia augustyniska do roku 1983, w: A. Trapè, Swięty Augustyn czlowiek - duszpasterz - mistyk, tłum. J. Sulowski, Warszawa 1987, 327-355.

${ }^{3}$ Por. M. Plezia, Księgozbiór katedry krakowskiej w świetle inwentarza z r. 1110, w: Silva rerum. Series nova, Kraków 1981, 16-29; I. Polkowski, Katalog rękopisów kapitulnych katedry krakowskiej, cz. 1: Kodexa rękopiśmienne 1-228, Kraków 1884, 4; Cz. Mazur, Teksty tacińskich Ojców Kościola w zbiorach polskich okresu średniowiecza i Odrodzenia, VoxP 3 (1983) z. 5, 455 466, spec. 456.

${ }^{4}$ Por. Z. Budkowa, Księgozbiór polskiego uczonego z XII/XIII wieku, „Studia Źródloznawcze" 1 (1957) 109-118; I. Polkowski, Katalog rękopisów, s. 4-5; Cz. Mazur, Teksty taciniskich Ojców Kościota, s. 457-458.

${ }^{5}$ Por. I. Polkowski, Katalog rękopisów, s. 7-24; Cz. Mazur, Teksty tacińskich Ojców Kościoła, s. 461 (ich dokładny wykaz). 
jedynym śladem jego zaginionej biblioteki ${ }^{6}$. Jan Długosz zaś informuje, że św. Jadwiga, królowa, posiadała i czytała homilie „czterech Wielkich Doktorów”, do których należał również św. Augustyn ${ }^{7}$. Jeśli zaś chodzi o późniejszy już okres, to również w bogatym księgozbiorze króla Jana Sobieskiego (16741696), obok mów św. Ambrożego, homilii św. Piotra Chryzologa, poezji św. Efrema i homilii maryjnych św. Jana Damasceńskiego, był również traktat O Państwie Bożym św. Augustyna ${ }^{8}$. Dzieła św. Augustyna, który cieszył się wielka powagą w filozofii i teologii średniowiecznej, spotykamy także wielokrotnie w rękopiśmiennych kodeksach i prywatnych bibliotekach profesorów Akademii Krakowskiej, którzy je nie tylko posiadali, ale zapewne na wykładach czytywali ${ }^{9}$. O obecności rękopisów dzieł św. Augustyna w Polsce pewne wyobrażenie może też dać analiza katalogu F. Römera ${ }^{10}$, z którego wynika, że najstarsze z nich znajdują się w bibliotece kapituły krakowskiej.

Warto tu też przypomnieć, że pierwszą patrystyczną książką wydrukowaną w Polsce, był opublikowany w 1476 r. w Krakowie u Kacpra Straubego kodeks zawierający właśnie dzieła (autentyczne i nieautentyczne) św. Augustyna pt. Omnes libri beati Augustini Aurelii ${ }^{1}{ }^{1}$. Inkunabuł ten znajdujący się w Bibliotece Jagiellońskiej, Czartoryskiej, Kórnickiej i Uniwersyteckiej KUL ${ }^{12}$ zawiera 14 następujących dziel: De doctrina christiana, De natura boni contra Manichaeos, De vera et falsa poenitentia, Speculum, De fide ad Petrum Diaconum, Soliloquia, De fuga mulierum, De contemptu mundi, De correptione et gratia, De dogmatibus ecclesiasticis, De disciplina christiana, De cura pro mortuis gerenda, De conflictu vitiorum et virtutum, De praedistinatione Sanctorum. Jest to pierwszych 14 pism drukowanych pod imieniem św. Augustyna na ziemi polskiej, z których tylko 7 należy faktycznie do niego. Trudno ustalić, czy zbiór

${ }^{6}$ Por. Encyklopedia wiedzy o ksiqżce, Wrocław 1971, 211 (później własność Jana Długosza); Cz. Mazur, Początki znajomości, s. 55; tenże, Teksty tacińskich Ojców Kościoła, s. 460.

${ }^{7}$ Por. Roczniki czyli kroniki stawnego Królestwa Polskiego X (ad annum 1399), Warszawa 1981, 302-303: „zajęla umysł i serce wyłącznie modlitwą i czytaniem ksiąg świętych, mianowicie Starego i Nowego Testamentu, homilii czterech Doktorów (omeliarum quattuor Doctorum), żywotów Ojców, kazań i opisów męki świętych, medytacji i kazań św. Bernarda i św. Ambrożego, Objawien św. Brygidy i wielu innych przełożonych z laciny na język polski”.

${ }^{8}$ Por. I. Komasara, Jan III Sobieski - mitośnik ksigg, Wrocław 1982, 129; W. Kania, Król Jan III Sobieski-zarliwy czytelnik pism Ojców Kościoła, VoxP 3 (1983) z. 5, 451-454, spec. 453.

${ }^{9}$ Por. W. Szelińska, Biblioteki profesorów Uniwersytetu Krakowskiego w XVi w począkach XVI wieku, Wrocław 1966, 57, 73, 81 (przyp. 109), 98, 99, 193, 194; L. Hajdukiewicz, Biblioteka Macieja z Miechowa, Wrocław 1960.

${ }^{10}$ Por. Die handschriftliche Überlieferung der Werke des heiligen Augustinus, Bd. III: Polen, Wien 1973, spec. 137-234.

${ }^{11}$ Por. Estreicher XII 293; J. Dyl, „Omnes libri beati Augustini Aurelii”. Pierwsza ksiażka patrystyczna wydrukowana w Polsce, VoxP 8 (1988) z. 15. 803-809.

12 Por. BJ Inc. 1987; BCzartoryski Inc. 56; BKór Inc.F 173; BKUL Inc. 119 adl; J. Czerniatowicz - Cz. Mazur, Recepcja antyku chrześcijańskiego w Polsce. Materiały bibliograficzne, t. 1: w. XV-XVIII, cz. 1: Autorzy i teksty, Lublin 1978, s. 5. 
tych dzieł jest przypadkowym zestawem, czy też dobranym wedhug określonego klucza, być może na jakieś konkretne zamówienie płynące z Krakowa dla potrzeb Akademii, duszpasterstwa lub szkół zakonnych. Łączyło się to niewątpliwie $\mathrm{z}$ ówczesną modą na św. Augustyna, który pod koniec średniowiecza zajmował pierwsze miejsce wśród Ojców Kościoła, ale nawet później, gdy w okresie Odrodzenia zaczęto wyżej cenić dzieła Jana Chryzostoma, które częściej wówczas występują w polskich bibliotekach, jego pisma zachowały swoją powagę. Od wprowadzenia bowiem w Polsce druku (1474) do końca XVI wieku z Ojców łacińskich najczęściej drukowano dzieła św. Augustyna; poczynając od mogunckiego druku De civitate Dei z 1473 r., jego poszczególne dzieła, czy też jego Opera omnia, wielokrotnie występują w różnych księgozbiorach polskich, zwłaszcza profesorów Uniwersytetu Krakowskiego. Tak np. Michał Falkner z Wrocławia posiadał wspomniane wyżej De civitate Dei, na którym nawet poczynił swoje noty marginalne. Dzieło to czytali również profesorowie: Stanisław Biel z Nowego Miasta i Marcin Łysy. Inni, jak Jakub z Szadka i Jan Sommerfeld posiadali i czytywali inkunabuły Listów augustyńskich, którymi w paryskim wydaniu z $1330 \mathrm{r}$. interesował się również dominikanin Pankracy Klemme z Gdańska, czytający także wydane w 1576 r. w Lyonie Objaśnienia do Psalmów ${ }^{13}$.

Jeśli zaś chodzi o pierwszy polski przekład pisma związanego $\mathrm{z}$ imieniem św. Augustyna, to było nim wydane w 1522 r. przez krakowskiego drukarza Hieronima Wietora anonimowe thumaczenie przypisywanego mu traktaciku (De vita christiana $)^{14}$ pt. Księgi świętego Augustyna Biskupa Hippońskiego o żywocie krześcijańskim, odkryte i opublikowane w 1914 r. przez A. Chmie$\mathrm{la}^{15}$, faktycznie jest to najprawdopodobniej dzieło Pelagiusza ${ }^{16}$. Pierwszym zaś tłumaczem już autentycznych pism Augustyna był ks. Jakub Wujek, który najpierw w wydanej w 1573 r. w Krakowie Postylli katolicznej (większej) umieścił przetlumaczone przez siebie przypisywane mu dwa kazania (s. 6669): Krótka rozprawa św. Augustyna o prawym bóstwie Syna Bozego i Ducha Świętego naprzeciwko arianom, sabelianom i ebionitom, i (s. 303) Święty Augustyn o chwalebnym Sakramencie $)^{17}$, a w drugiej wersji tej publikacji, czyli

${ }^{13}$ Por. Cz. Mazur, Teksty tacińskich Ojców Kościota, s. 462; tenże, Poczq̨tki znajomości, s. 56; zob. wyżej n. 9.

14 Por. PL 40, 1031-1046.

15 Druk ten z pierwotną podobizną $\mathrm{H}$. Wietora wydał Adam Chmiel z uwagami językowymi Jana Łosia: Kraków 1914, ss. 25, Nakładem Akademii Umiejętnosci. Materiały i Prace Komisji Językowej, t. VII, 1-25. Jego tlumaczem był być może Balthasar Opeć, którego Żywot Jezu Krysta został wydany w tym samym roku u $\mathbf{H}$. Wietora. Więcej o tym druku zob. A. Bober, Pseudo. Augustyriskie dzieła ascetyczne w Polsce, RTK 4 (1957) z. 2, 40-41 (O żywocie krzescijańskim).

${ }_{16}$ Tak CPL 730 i Altaner, choć niektórzy starsi badacze (Holtensius) uważają, że jego autorem jest pelagianin Fastydiusz z Brytanii, PL. 50, 383-402.

17 Por. Postilla catholica, to jest kazania na każdq niedzielę i na każde święto przez caly rok, Kraków 1573, s. 66-69 i s. 300; J. Czerniatowicz - Cz. Mazur, Recepcja antyku chrześcijańskiego 
wydanej w 1596 r. Postylli katolicznej mniejszej, przetłumaczonych aż 9 kazań pod nazwiskiem Biskupa $z$ Hippony ${ }^{18}$, $z$ których tylko 4 należą do niego, 2 do Cezarego $z$ Arles, a reszta to centony przypisywane tylko Augustynowi.

Tenże ks. J. Wujek jest również pierwszym polskim thumaczem fragmentu augustyńskiego traktatu De civitate Dei (XXII 8), który umieścil w swojej Postylli katolicznej większej o świętych, na uroczystość św. Szczepana pt. „Świętego Augustyna Relatia o cudach rozlicznych, które się stały na różnych mieyscach przez Reliquie a przez wzywanie Szczepana świętego, wyięta z ksiąg iego o Mieście Bożym"19. Fragmentu tego użył Wujek jako argumentu przeciw heretykom uwłaczającym czci Świętych, zachęcając do lektury tego przekładu: „Tu się zbieżcie / a to czytaycie wszyscy / którzy z świętymi Bożymi dziwne burdy a woyny wiedziecie: nazywaiąc ie umarłymi / a powiedając / że nam nic pomóc nie mogą: a iż ich Reliquij mieć w ućciwości / a do ich kościołów pielgrzymować / y grobów ich nawiedzać nie potrzeba". Zarówno mowy jak i powyższy traktat tłumaczył Wujek według mało krytycznego wydania teologów lowańskich, opublikowanego w Anvers w 1576-1577 przez K. Plantina ${ }^{20}$, stąd też tyle apokryfów wśród jego przekładów.

w Polsce, dz. cyt., s. 84-85, nr 530; A. Bober, Wujek jako thumacz św. Augustyna, VoxP 3 (1983) z. 5 , 409-417, spec. 416; tenże, Wkład jezuitów do polskiej patrystyki, w tegoż: Studia i teksty patrystyczne, Kraków 1967, 180.

${ }^{18}$ Por. J. Wujek, Postilla katholicka mniejsza to jest Krótkie kazania abo wyktady świętych Ewangelij [...] wedle nauki prawdziwej Kościoła Chrześcijañskiego Powszechnego. [Postilla catholica minora seu breves contiones sacrae]. Z nowu z pilnościq̨ przejźrzana, poprawiona i po czwarte wydana. Przydano tez kazania których nie dostawato i kilka kazań z Doktorów starych, Kraków 1596, A. Piotrkowczyk: 1). ss. 30-32: Kazanie o przygotowaniu na dzień Narodzenia Pańskiego (Serm. 2. de tempore). 2). ss. 109-111: Kazanie św. Augustyna o Wielkim Poście czterdzieści dni (Serm. 68), autentyczna mowa 205. PL 38, 1039-1040. 3). ss. 124-125: Kazanie św. Augustyna o spowiedzi (Serm. de tempore 66). 4). ss. 199-201: Kazanie św. Augustyna o Pańskim Zmartwychwstaniu (De temp. serm. 141), autentyczna mowa 231, PL 38, 1104-1107. 5). ss. 229-230: $\mathrm{Na}$ [...] dzień Wniebowstąpienia Pańskiego kazanie św. Augustyna (Serm. de tempore 175). 6). ss. 552-554: Na dzień wszech Świętych kazanie trzecie Augustyna św. o zapłacie niewymownej wszystkich Swiętych w niebie (Serm. de Sanctis 23). 7). ss. 560-561: Na dzień Zaduszny drugie kazanie św. Augustyna o słowiech Apostolskich: abyśmy się z umarłych nie smucili (Serm. 32 de verbis Apost.), autentyczna mowa 172, PL 38, 935-937. 8). ss. 583-585: Na poświęcenie kościoła kazanie drugie św. Augustyna (Serm. 5 de dedica. Eccle.), autentyczna mowa 336, PL 38, 1471 1475. 9). ss. 593-595: Kazanie Augustyna Sw. o słowiech Apostolskich: Wszyscy się mamy pokazać przed stolicą sędziego... (Serm. 34 de verbis Apost. 2. Cor. 5); A. Bober, Wujek jako thumacz św. Augustyna, ss. 411-416 (szczególowe omówienie tych homilii oraz ich weryfikacja).

${ }^{19}$ Por. Postilla catholica, to jest kazania na ewangelie niedzielne y odswiętne przez caly rok wedtug wyktadu samego prawdziwego Kościota s. Powszechnego, t. 2: O Świętych, cz. 1: Oźimia, Kraków 1584, przedruk W. Jaworskiego, Kraków 1870, 178-186; A. Bober, Wujek jako thumacz św. Augustyna, s. 416; W. Eborowicz, Ks. Jakub Wujek thumaczem "Państwa Bozego" św. Augustyna, "Studia Pelplińskie" 2 (1971) 251-252.

${ }^{20}$ O tym wydaniu por. J. de Ghellinc, Patristique et Moyen Âge, III, Paris 1948, 392-393; A. Bober, Wktad jezuitów do polskiej patrystyki, art. cyt., s. 180. 
W tym też czasie, w XVI wieku, pisma św. Augustyna są czytywane nie tylko, jak wspominaliśmy, na polskich dworach królewskich, ale i na biskupich. Biskup włocławski Hieronim Rozdrażewski (1535-1600) posiadał bazylejskie wydanie Erazma dzieł św. Augustyna z 1528 roku $^{21}$. Kardynał Stanisław Hozjusz (1504-1579) natomiast, jak sam wyznał i jak napisał jego biograf Stanisław Reszka, aż 6 razy przeczytał w całości dzieła św. Augustyna, zaznaczając, że choćby nawet 100 razy je czytał, to zawsze znajdywał w nich dla siebie coś użytecznego ${ }^{22}$; w liście do P. Tomickiego nazywał go ,princeps ille theologorum divus Augustinus"23, który według zgodnej opinii wszystkich zajmuje pierwsze miejsce między lacińskimi teologami"24. Posiadał też własny zbiór pism św. Augustyna, „który przez całe życie pilnie studiował”, a tuż przed śmiercią polecił przekazać swemu zaufanemu sekretarzowi Tomaszowi Treterowi ${ }^{25}$. Kilka dni przed nią dziękował Bogu, że pozwolił mu dożyć 76 . roku życia, czyli wieku boskiego Augustyna ${ }^{26}$.

W dwóch następnych wiekach XVII-XVIII w przeciwieństwie do Zachodu, gdzie pojawiło się wiele poważnych prac i wydań pism św. Augustyna (jak np. wydanie paryskie w 10 tomach w 1555 , i wspomniane lowańskie w 1576 , czy też

${ }^{21}$ Por. Cz. Mazur, Literatura patrystyczna w Polsce w okresie Odrodzenia, „Summarium TN KUL" 1976, nr 5(25), 17-22.

${ }^{22}$ Por. S. Reszka, Stanislai Hosii vita, Pelplini 1938, s. 28: „In legendis enim et evolvendis veterum Patrum et Ecclesiae Dei Doctorum immensis voluminibus assiduam sine ulla intermissione operam navabat, maxime autem omnium sanctissimi Doctoris Augustini; quem sexies a capite ad calcem legisse, ac centies si legisset, ex eo cotidie proficere potuisse memorabat"; J. Ujda, Kardynat Stanisław Hozjusz - polski wielbiciel i naśladowca św. Augustyna, „Przegląd Katolicki" 66 (1930) nr 33, s. 513; J. Umiński, Zagadnienie wptywu św. Augustyna na Stanistawa Hozjusza, „Przegląd Teologiczny” 11 (1930) 524-530; J.A. Kalinowska, Stanistaw Hozjusz jako humanista (1504-1579). Studium $z$ dziejów kultury renesansowej, Olsztyn 2004, 10, 21-22, 48, 55, 93, 96, 121, $126,137,143,147-150$.

${ }^{23}$ Hosius Petro Tomicki, Cracoviae d. 8 Aprilis 1528, w: P. Stanislai Hosii Epistolae, tomus I, Cracoviae 1879 , nr. $3,3$.

24 Hosius L. Bonamico, Cracoviae 12 Februarii 1536, tamże, nr. 16, s. 36: „ut intelligas, quantum apud me tua valeat auctoritas, exemplo tuo provocatus ipse quoque faciendum putavi, ut me totum sacris litteris traderem, Augustinum legendum mihi sumpsi, qui videtur inter latinos theologos omnium concessu principem locum obtinere".

25 Por. Epistola Stanislai Rescii de transitu et dormitione... D. Stanislai Hosii... ad Joannem Hosium de Bezdanij fratrem eius, w: Hosii Opera omnia, Coloniae 1584, II, ss. 490: „Postea me [Reszkę] accersito, de quibusdam adhuc rebus animo plane praesentissimo mandata dedit: et inter alia ut opera D. Augustini, cuius in omni vita sua semper fuit studiosissimus, Thomae Tretero familiari dilecto cederent ordinavit: ea vero quae Thomas habebat, Zolcinio assignavit".

${ }^{26}$ Por. Epistola Rescii ad Joannem de Bezdan, w: Hosii Opera omnia, II, Coloniae 1584, s. 488: „,iam enim tempus resolutionis meae instat Imo vero quantas maximas animus meus capere potest, Deo et Salvatori meo Jesu Christo ago et habeo gratias, quod non ullis meis meritis, sed per summam et infinitam misericordiam suam ad eum aetatis annum me pervenire voluerit, ad quem pervenit sanctissimus et doctissimus ille doctor Ecclesiae, quem ego prae caeteris omnibus in vita mea colui, et imitari quantum potui conatus sum, Divus Augustinus, qui et ipse in 76 . anno aetatis suae sanctam suam animam Deo Salvatori suo reddidit". 
wcześniej bazylejskie), w Polsce zauważamy wyjątkowy wzrost zainteresowań jego dziełami ascetycznymi, które niemal w całości do nicgo nie należały ${ }^{27}$; przedruków łacińskich tekstów tych pism u nas w zasadzie nie było, natomiast w różnych miejscach, czasie i formach pojawiało się wiele ich przekładów ${ }^{28}$. I tak w 1617 r. ukazał się w jezuickiej drukarni w Wilnie tomik z przekładem 5 pseudoaugustyńskich dziełek, dokonanym 20 lat po śmierci Wujka, przez jezuitę Jana Alandusa, mylnie przypisywanym starościcowi bobrójskiemu Piotrowi Kazimierzowi Tryźmie, który faktycznie był tylko jego fundatorem, a mianowicie: Św. Augustyna ksiąg pięcioro: Rozmyślania (Meditationes), Rozmowy tajemne z Bogiem (Soliloquia animae ad Deum), Broń duchowa (Manuale), O skrusze serca (De contritione cordis), O marności świata (De vanitate saeculi). Teraz nowo $z$ tacińskiego jezyka na polski wedlug pewniejszych egzemplarzów przetozione i paragrafami rozdziatów oznaczone przez Piotra Kazimierza Tryznę, starościca bobrójskiego ${ }^{29}$. Nie wiemy, kto jest autorem wyboru tych pism, z których zadne nie należy do Biskupa Hippony ${ }^{30}$, a którego wielkie imię mialo im zapewnić powodzenie. Po tłumaczeniu homilii i fragmentu De civitate Dei przez J. Wujka jest to pierwszy w Polsce przekład kilku dziełek Pseudo-Augustyna w całości, który w latach 1617-1798 cieszyl się ogromną popularnością i doczekał się aż dwunastu odrębnych wydań w Krakowic (1644), Lublinie (1697), Warszawie (1759), Nieświeżu (1759), ponownie w Wilnic (1760), Poznaniu (1760), Poczajowie (1777), Połocku (1788), znów w Wilnie (1788) i w Warszawie (1798), i na różne ascetyczne sposoby był pod imieniem Biskupa Hippony wykorzystywany, jeszcze w 1928 r. we Lwowie na nowo przez ks. Bobicza przetłumaczony, bez jakichkolwiek podejrzeń o ich autentyczność, mimo iż na Zachodzie powszechnie ją negowano ${ }^{31}$. Ich niesłychana popularność zdawała się zasadzać na ich uczuciowej treści, odpowiadającej ówczesnemu spoleczeństwu polskiemu, stając się dla niego nie tylko podręcznikiem do rozmyślań, ale również książeczką do nabożeństwa w kościele i w domu, a nawet katechizmem na codzień.

Rozczytywał się w nich również podczas pobytu w Nancy nawet eks-król polski Stanisław Leszczyński (1677-1766), dla którego kapelan-jałmużnik Dionizy Clement (1706-17771) sporządził z tych trzech apokryfów (Meditationes,

${ }^{27}$ Por. A. Bober, Pseudoaugustyniskie dzieta ascetyczne w Polsce, RTK 4 (1957) z. 2, 39-77.

${ }^{28}$ Por. J. Czerniatowicz- Cz. Mazur, Recepcja antyku chrześcijańskiego w Polsce, dz. cyt., s. 625 .

${ }^{29}$ Wilno 1617, Drukarnia Akademiey Societatis Jesu, 4, ss. 136; każde z nich omawia szczegółowo ks. A. Bober, Pseudoaugustyńskie dziela ascetyczne, s. 46-49.

39) Ich tekst laciński opracowali Mauryni w zbiorowym wydaniu pism św. Augustyna, które później przedrukowal J. Migne, por. Meditationes, PL 40, 901-942; Soliloquia animae ad Deum, PL 40,863-898; Manuale, PL 40, 951-968; De contritione cordis, PL 40, 943-950; De vanitate saeculi, PL 40, 1213-1214.

31 Negowali ja już Mauryni, por. Admonitio, PL 40, 449-452. 
Manuale, Soliloquia) małą antologię, zestawiając wybrane z nich teksty wokół dwóch tematów - dobroci Bożej i męki Chrystusa oraz wydał w 1740 r. pt. Entrétiens de l'âme avec Dieu. Antologię tę przetłumaczył na język polski wierszem i wydał razem z francuskim tekstem Clementa w Nancy w 1745 r. król Stanisław Leszczyński ${ }^{32}$. Książka ta znowu wzbudziła duże zainteresowanie, była wielokrotnie wydawana i na nowo na język polski tłumaczona przez ks. J. Łubieńskiego (Brunsberg 1761) i prozą prawdopodobnie przez ks. F. Bohomolca (Warszawa 1770) ${ }^{33}$.

Oprócz powyższych pseudoaugustyńskich pism ascetycznych jeszcze dwa inne augustyńskie apokryfy wzbudziły duze zainteresowanie Polaków. Pierwszy z nich to tzw. Psałterz św. Augustyna, będący, jak się wyrazil ks. A. Bober, „lichą łataniną wersetów Dawidowych", które jakiś duchowny zlepił w osiem próśb o gorliwość w służbie Bożej, a dla nadania mu powagi przypisał św. Augustynowi, jakoby ten miał go ułożyć zaraz po nawróceniu dla swojej matki na pamiątkę przeżytych $\mathrm{z}$ nią wspólnie chwil ${ }^{34}$; był on również na język polski thumaczony ${ }^{35}$ oraz często dołączany do wydań powyższej antologii.

Drugim takim popularnym wśród Polaków apokryfem było przypisywane św. Augustynowi średniowieczne dziełko benedyktyńskiego opata Adso pt. Antychryst ${ }^{36}$; powstało ono ok. $954 \mathrm{r}$. w związku z rozpowszechnianymi wówczas pogłoskami o zbliżającym się końcu świata, a jego osnowę Adso mógł zaczerpnąć z De civitate Dei (XX 11) św. Augustyna, gdzie jest również mowa o antychryście; i ono zostało przetłumaczone w XX wieku przez ks. J. Czuja ${ }^{37}$.

Obok tej dominującej apokryficznej literatury augustyńskiej istniała oczywiście w tym czasie w Polsce, choć w mniejszym zakresie, literatura ściśle augustyńska, która przedstawia dość szeroką panoramę pism głównie w języku

${ }^{32}$ Por. Entrétiens de l'âme avec Dieu, tirés des paroles de Saint Augustin dans ses méditations, ses soliloques et son manuel. Par M. l'abbé Clément docteur en théologie. Rozmowy duszy z Panem Bogiem wybrane ze stów św. Augustyna w medytacjach y inszych xsiegach jego, B. m. (Nancy) R.P. MDCCXLV (1745), 8, ss. 403. Od strony 305 jest: Psautier des S. Augustin. Psatterz św. Augustyna. Tekst francuski prozą, a przekład polski wierszem, którego tłumaczem jest król Stanisław Leszczyński.

${ }^{33}$ Por. J. Czerniatowicz - Cz. Mazur, Recepcja antyku chrześcijaniskiego w Polsce, s. 6, nr 28 29; J. Sulowski, Augustyn w Polsce, s. 328-329; A. Bober, Pseudoaugustyískie dzieła ascetyczne, s. $68-70$.

34 Jego tekst laciński, ale bez wstępu i komentarza, wydrukowali także Mauryni, por. PL 40, 1135-1138; A. Bober, Pseudoaugustyniskie dzieła ascetyczne, s. 70-71.

${ }^{35}$ Por. Psatterz Augustyna św., który kwoli nabożeństwa matki swej ulożyt, przez Adryana $z$ Wieszczyc Wieszczyckiego przelożony, Kraków 1650, 4, knlb 12; J. Czerniatowicz - Cz. Mazur, Recepcja antyku chrześcijariskiego w Polsce, s. 12, nr 62.

36 Jego niepełny tekst laciński De Antichristo wydali Mauryni w dodatku do pism św. Augustyna, PL 40, 1131-1134, a w całości wśród pism Adso, PL 101, 1289-1298; por. A. Bober, Pseudoaugustyńskie dzieta ascetyczne, s. 72-74.

37 Por. Sw. Augustyn, O antychryście - księga jedna, „Gazeta Kościelna” 28 (1921) s. 7-8 i 23. 
lacińskim, rzadziej polskim lub w którymś z sąsiednich (czeskim, niemieckim, litewskim, a także francuskim lub włoskim). Są wśród nich augustyńskie pisma całe lub w formie antologii, często kazania, a także traktaty teologiczne lub filozoficzne. Jeśli chodzi o teksty, to warto tu wymienić najpierw dwie najstarsze augustyńskie antologie: krótką antologię (po wstępie - 35 wybranych tekstów) ks. Piotra Skargi (1536-1612) przy Żywocie św. Augustyna ${ }^{38}$ oraz wydane w 1686 i w 1687 roku w Warszawie, a potem w Kaliszu Nauki chrześcijańskie $z$ ksiag św. Augustyna wybrane przez biskupa Andrzeja Chryzostoma Zaluskie$\mathrm{go}^{39}$, a także cale pisma, jak wydane w 1530 r. w Krakowic staraniem Piotra Tomickiego De moribus Ecclesiae Catholicae ${ }^{40}$, czy wydane przez Sebastiana z Felsztyna w 1536 r. również w Krakowie De musica ${ }^{41}$ oraz Confessiones w przekladzie polskim przez Szymona Karpińskiego (1641-1721) ${ }^{42}$, czy wreszcie ciesząca się dużym powodzeniem, wydana po raz pierwszy u Wietora w 1536 r. w Krakowie, a później wielokrotnie w różnych miejscach Polski wznawiana, Regula S. Augustini episcopi w języku lacińskim lub polskim, do której często dodawano inne późniejsze reguly zakonne ${ }^{43}$ lub też pisane do niej specjalne komentarze ${ }^{44}$; najwcześniej wydanych augustyńskich kazań, oprócz tych przethumaczonych prze J. Wujka, warto tu wymienić wydane w 1578 r. Kazanie św. Augustyna przeciwko opilstwu $u^{45}$, oraz późniejsze z połowy XVIII wieku Kaza-

${ }^{38}$ Por. Zywoty Swiętych Starego i Nowego Zakonu na każdy dzień przez caty rok, Kraków 1935, III 385-395 (Żywot), 395-402 (Nauka św. Augustyna, dzisiejszym kacerstwom przeciwna).

${ }^{39}$ Por. najpierw Nauki chrześcijańskie z ksiagg św. Augustyna wybrane, z tacińskiego na polski jezyk przez jednego kaptana [Andrzeja Chryzostoma Zatuskiego] przettumaczone r. 1686, Warszawa [1687], Coll. Schol. Piarum, 4, knlb. 138; później: Nauki chrześcijańskie na polski jezyk frzethumaczone przez Andrzeja Chryzostoma Zatuskiego, naprzód anonime r. 1687 w Warszawie wydane, potym w Typografii kaliskiej S. J. przedrukowane i r. 1730 publikowane, Kalisz 1730, Coll. Soc. Jesu, 2, knlb. 74 .

${ }^{40}$ Por. De moribus Ecclesiae Catholicae liber I. Sub auspicio Petri Tomicii ed. per loannem Cervum Tucholiensem, Kraków 1530, F. Ungler, 4.

${ }^{41}$ Por. De musica dialogi VI Erasmi [Ciołek] abbatis Mogilensis auspicio editi per Sebastianum de Felstin artium baccalarium ac Sanocensis ecclesiae paroccum, Kraków 1536, H. Wietor, 4.

${ }^{42}$ Por. Confessiones - wydane zostały w przekładzie polskim przez Szymona Karpińskiego, żyjącego w latach 1641-1721, jak podaje J. Brown, Bibiblioteka pisarzów T. J., nr 4, Poznań 1862, s. 214

${ }^{43}$ Por. Regula s. Augustini episcopi et Constitutiones fratrum Ord. Praedicatorum, Kraków 1536, H. Wietor, 16, k. 78, 36 nlb; później: Regula beatissimi Aurelii Augustini de communi vita clericorum. Huic adiecta collectio Petri Claretae super statuta canonicorum regularitum, Kraków 1618, M. Andrzejowczyk, 8, knlb. 19, 154, 36 nlb.; inne późniejsze wydania zob. J. Czerniatowicz - Cz. Mazur, Recepcja antyku chrześcijańskiego w Polsce, s. 12-14, nr 64-79, 83, 85-92.

${ }^{44}$ Por. np. Na regulę Augustyna św. wyklad przez Servacjusa de Lairnes uczenie i dostatecznie w języku tacińskim napisany, a teraz na polski przetożony, skrócony i w summę zebrany, Kraków 1617, F. Cezary, 4, knlb. 16, ss. 188; inne późniejsze zob. J. Czerniatowicz - Cz. Mazur, Recepcja antyku chrześcijańskiego w Polsce, s. 14-15, nr 80, 82, 84.

${ }^{45}$ Por. H. Powodowski, Korab zewnętrznego potopu. Przydane jest na końcu Kazanie św. Augustyna przeciwko opilstwu, Kraków 1578, M. Scharffenberg, 8, knlb. 14, ss. 315. 
nie o wydawaniu dziesięcin ${ }^{46}$. Z traktatów zaś teologicznych na uwagę zasługują m.in. wydana ok. 1563 r. w Pińczowie mała antyariańska rozprawa Ariana haeresis, quae omnibus christianis detestanda est, succincte describitur a divo Aurelio Augustino in libro De haeresibus octoginta octo ${ }^{47}$ oraz wydane w Wilnie w 1775 r. Conclusiones philosophicae et doctrina patris Augustini ${ }^{48}$, a z późniejszych, już po polsku, wydana u Jezuitów w 1698 r. w Poznaniu przez Jana Morawskiego Droga przed Bogiem śmierć świętych albo dyspozycja na śmierć dobrq, nauką teologii i pobożnymi z Pisma św. i z Ojców św., mianowicie św. Augustyna affektami objaśniona naprzód po łacinie a potem po polsku ${ }^{49}$, oraz wydane u Bazylianów w 1786 r. w Wilnie Dzieło osobliwej wszechmocnej prawicy Boskiej, to jest cudowne nawrócenie św. Aureliusza Augustyna ${ }^{50}$.

Powyższe dzieło nawiązuje w pewnym stopniu do rozpowszechnionej na początku XVIII wieku w Europie zachodniej mody przedstawiania tematu nawrócenia św. Augustyna w twórczości artystycznej i teatralnej, a nawet muzycznej $^{51}$, która przyniesiona została także do Polski: mamy tu do odnotowania oratorium pt. La conversione di S. Agostino, śpiewane w Wielką Sobotę przy Grobie Pańskim po włosku z muzyką Jana Adolfa Hasse, w drezdeńskiej kaplicy królewsko-elektorskiej, napisane przez synową króla polskiego Zygmunta III Antonię Valpurgis, a przethumaczone w następnym roku (1751) w Kielcach na język polski przez ks. Józefa Załuskiego ${ }^{52}$.

Wiek XIX to na Zachodzie okres rozkwitu Oświecenia, a w Polsce czas rozbiorów i powstań narodowych, które mimo sympatii romantyzmu do starożytności, nie sprzyjały zbytnio rozwojowi nauk historycznych i teologicznych. We Francji mimo to w połowie wieku ukazuje się monumentalna edycja dzieł

${ }^{46}$ Por. Kazanie o wydawaniu dziesięcin, Kalisz poł. XVIII wieku, Drukarnia Jezuitów, 2, knlb. 3 .

47 Pińczów ca. 1563, Daniel z Łęczycy, 4, knlb 5.

48 Por. Conclusiones philosophicae et doctrina [...] patris Augustini ab erroribus philosophorum gentilium vindicata a Aegidio Columna cardinali erecta depromptae, Wilno 1755, Typis PP. Minorum Conventualium, 4, knlb 4; inne zob. J. Czerniatowicz - Cz. Mazur, Recepcja antyku chrześcijaniskiego $w$ Polsce, s. 17-25, nr 100-101. 103, 105-110, 112-113, 115-120, 126-138, 142, 149.

${ }^{49}$ Poznań 1698, Coll. Soc. Jesu, 8, ss. 438.

${ }^{50}$ Por. Caussinus Mikołaj, Dzieło osobliwej wszechmocnej prawicy Boskiej to jest cudowne nawrócenie św. Aureliusza Augustyna, po francusku napisane przez Mikotaja Kausino SJ, na jezyk wtoski przettumaczone od Pana Ziuata, weneckiego kawalera, z wtoskiego zaś na polski przez X. Jana Mackiewicza. [Opus de conversione s. Augustini] Wilno 1786, Druk. XX Bazylianów, 8, knlb. 8, s. 126; inne polskie zob. J. Czerniatowicz - Cz. Mazur, Recepcja antyku chrześcijaískiego w Polsce, s. 19, nr 111 i 114; s. 20, nr 120; s. 121, nr 121; s. 22, nr 128 i 130; s. 24, nr 141 i 143.

51 Por. Cintio Rotondi, La conversione di S. Agostino, Roma 1705 (Bibliotheca Vaticana, Ferraioli IV 8620), zawiera ponad 50 tego rodzaju oratoriów i kompozycji literackich.

52 Tekst włoski i jego przeklad polski zob. VoxP 8 (1988) z. 14, 133-167 (Osiemnastowieczny melodramat o nawróceniu św. Augustyna. Wstęp i opracowanie B. Degórski); zob. J. Czerniatowicz. - Cz. Mazur, Recepcja antyku chrześcijańskiego w Polsce, s. 24-25, nr 145-147; J. Sulowski, Augustyn w Polsce, s. 330-331. 
Ojców Kościoła w wydaniu J. Migne'a ${ }^{53}$, a w Niemczech pierwsze podręczniki patrologii ${ }^{54}$. Również na terenie Polski pojawia się wówczas w 1879 r. w Krakowie pierwszy polski podręcznik patrologii - Patrologia - Ojcoznawstwo kanonika warszawskiego J. Szpaderskiego ${ }^{55}$, a 25 lat później przekład Patrologii G. Rauschena w polskim tłumaczeniu J. Gajkowskiego ${ }^{56}$, w Krakowie zaś krystalizowała się szkoła filologiczna, która miała się zająć także pismami Ojców Kościoła. $Z$ interesującej nas tematyki na uwagę zasługują w tym okresie dwie pierwsze polskie augustyńskie biografie: Życie św. Augustyna, Biskupa Hipponeńskiego, Oyca i Nauczyciela Kościoła Bożego autorstwa Mateusza Gladyszewicza $^{57}$ i anonimowe Święty Augustyn Biskup Hippo w czwartym wieku po narodzeniu Chrystusa Pana ${ }^{58}$, a pod koniec wieku - anonimowy przekład A. Hatzfelda, Św. Augustyn, Ojciec i Doktor Kościoła ${ }^{59}$. W tym czasie pojawiły się też, głównie w Krakowie, pierwsze polskie przekłady całych autentycznych pism św. Augustyna, a mianowicie: już w 1855 roku $O$ mieście Bożym pierwszych ksiag pięcioro w tłumaczeniu wspomnianego już wyżej Mateusza Gladyszewicza ${ }^{60}$, S. Aureliusza Augustyna Biskupa Hippony o kazaniu Pańskim na górze według Mateusza ksiagg dwie w thumaczeniu anonimowym $^{61}, O$ prawdziwości religii katolickiej podług św. Augustyna wolnym przekładem Leona Rzewuskiego ${ }^{62}$, a także aż dwa przekłady jego Wyznań - w 1844 roku w Wilnie Michała Bohusza Szyszki ${ }^{63}$ i w 1847 roku w Krakowie Piotra Pękalskiego ${ }^{64}$. Trzeba tu też do nich doliczyć raz po raz wznawiane i uzupełniane różnymi zakonnymi dodatkami przekłady Reguły św. Augustyna $a^{65}$, wy-

${ }^{53}$ Por. Patrologiae cursus completus. Series Graeca, 1-162, Paris 1857-1866; Series Latina, 1-222, Paris $1878-1890$.

${ }^{54}$ Por. J. Möhler, Patrologie, Ratisbonae 1840; J. Fessler, Institutiones patrologiae, I-II, Oenipotente 1850-1851; G. Rauschen, Grundriss der Patrologie, Freiburg i. Br. 1903.

${ }_{55}$ Patrologia - Ojcoznawstwo albo nauka o Oycach Kościola Katolickiego i znakomitych pisarzach kościelnych, Kraków 1879, ss. 309.

${ }^{56}$ Por. Zarys patrologii ze szczególnym uwzględnieniem historyi dogmatów, tlum. J. Gajkowski, Warszawa 1904.

${ }^{57}$ Kraków 1832, ss. 149.

58 Warszawa 1877.

59 Warszawa 1899, ss. 239.

6r) Kraków 1835 , ss. 392

${ }^{61}$ Kraków 1854 , ks. I ss. $166+$ ks. II ss. 167-336.

${ }^{62}$ Kraków 1853, ss. 229.

63 Wilno 1844, cz. 1 i cz. 2; Wilno 1882; wydanie nowe, Wilno 1903, 1912, 1914, 1920, 1923.

64 Kraków 1847.

65 Por. Reguła św. Augustyna i Konstytucye zakonnic św. Urszuli Instytutu Burdygalskiego, potwierdzone przez Pawta V dnia 5111618 i powtónie potwierdzone przez Klemensa IX dnia $12 X$ 1667, Poznań 1871, ss. 226; 1895, 1908, 1930, 1937; Regula św. Augustyna wraz z ustawami zakonu s. Jana Bozego przez Oyca ś. Pawta V potwierdzona z przydatkiem różnych rezolucyj... jako też generalnych dekretów, niektóre punkta tychże konstytucyj objaśniajacych i tagodzqcych, Warszawa 1836, ss. 293. 
bory jego kazań i homilii ${ }^{66}$, wśród których na szczególną uwagę zasługuje opublikowany w 1858 roku w Poznaniu zbiór Pięćdziesiąt homilij św. Augustyna ${ }^{67}$, którym anonimowy thumacz chciał uczcić spóźniony jubileusz urodzin Biskupa Hippony; tłumacz nie znał wydania Migne'a (co nie świadczy zbyt dobrze o wysokim poziomie polskiej patrologii), ale posłużył się edycją antwerpską z 1576 roku - przepisywanym i przedrukowywanym przez parę wieków zbiorem homilii, powstałym w VI wieku w Galii, z którego tylko 23 mowy pochodzą od św. Augustyna, a 19 od Cezarego z Arles i innych autorów $^{68}$, a także przypisywanych mu kilka apokryficznych pism dewocyjnych $^{69}$. Już powyższy wykaz publikacji augustyńskich świadczy, że mimo niesprzyjających warunków, zainteresowanie postacią i dziełami Biskupa Hippony nie było aż takie małe, choć ograniczało się ono głównie do biografii i przekładów.

Na początku XX wieku pojawiają się również pierwsze polskie rozprawy dotyczące myśli i nauki św. Augustyna, jak np. dwie stosunkowo obszerne monografie Maurycego Straszewskiego poświęcone jego filozofii ${ }^{70}$, czy też A. Gerstmanna o jego poglądach katechetyczno-homiletycznych ${ }^{71}$, N. Cieszyński zaś w 1919 r. informuje polską opinię publiczną o odkryciach augustyńskich dokonanych w 1917 roku przez D. Morina ${ }^{72}$; wtedy też ukazuje się trzeci z kolei polski Żywot św. Augustyna w opracowaniu ks. Jana Czuja ${ }^{73}$. W okresie tym pojawiają się także kolejne przekłady dzieł Biskupa Hippony, a mianowicie, obok ciągle modnych pseudoaugustyńskich traktatów dewocyjnych ${ }^{74}$, dwa kolejne przekłady jego Wyznan - częściowe, ale wydane w Bibliotece Narodowej Krystyny Wisłockiej-Remerowej ${ }^{75}$ ze wstępem i objaśnieniami J. Kowalskiego, który też poświęcił tej publikacji trzy artykuły ${ }^{76}$, oraz pełne ks. Jana

${ }^{66}$ Por. Kazania i homilie różne, tłum. J. Krzyszkowski, Wilno 1823, 1824.

${ }^{67}$ Por. Pięćdziesiąt homilij św. Augustyna, Poznań 1858, Nakładem i czcionkami N. Kamieńskiego i Spólki, ss. IV + 263.

68 Por. A. Bober, Pięćdziesiąt homilii św. Augustyna. Karta z dziejów polskiej patrystyki, RTK 26 (1979) z. 4, 145-161.

69 Por. Pisma świętego Augustyna (Rozmyślania, Rozmowy duszy z Bogiem) z laciny przełożył ks. P. Wawrowski, Gniezno 1852, ss. 243.

${ }^{70}$ Por. Filozofia św. Augustyna na tle epoki, Kraków 1905; tenże, Św. Augustyn największy z filozofów chrześcijańskich, Kraków 1910.

71 Por. Zagadnienia katechetyczne i homiletyczne u św. Augustyna, Lwów 1908.

72 Por. Św. Augustyn na tle kazań świeżo odkrytych, PP 36 (1919) t. 141-142, 432-444.

${ }^{73}$ Kraków 1928; wyd. II Kraków 1930; wyd. III Warszawa 1952.

${ }^{74}$ Por. Księgi św. Augustyna, biskupa hippońskiego o żywocie krześcijańskim, wyd. J. Łos, Kraków 1914, PAU; $S w$. Augustyna Enchiridion. Księga podręczna, tłum. J. Babicz, Lwów 1928, Biblioteka Religijna; Sw. Augustyn, Ksiega rozmów z Bogiem (Soliloquia), thum. Maria Emilia Niepokalanka, Lwów 1928, Biblioteka Religijna.

${ }^{75}$ Wyznania ks. I·X, Kraków 1929, BN ser. II 45.

${ }^{76}$ Por. À propos d'une nouvelle traduction polonaise de "Confessiones" de St. Augustin, „Bulletin de l'Association G. Budé" 1926, nr 12, Juillet s. 48-50; tenże, Est-ce qu'Augustin se 
Czuja $^{77}$, a przede wszystkim aż 7 tomów i 12 tytułów dzieł augustyńskich, wydanych w zapoczątkowanej w 1924 r. w Poznaniu serii Pisma Ojców Kościoła pod redakcją J. Sajdaka ${ }^{78}$.

Do dużego, wprost przełomowego, ożywienia zainteresowań postacią i nauką św. Augustyna przyczynił się, również w Polsce, obchodzony w 1930 r. jubileusz 1500-lecia jego śmierci. Nie będziemy tutaj wyliczać wszystkich związanych $\mathrm{z}$ tą rocznicą polskich publikacji, bo jest ich wiele, a okres 1918-1954 omówił stosunkowo dokładnie ks. W. Eborowicz ${ }^{79}$ i są one umieszczone we wspomnianej na wstępie augustyńskiej bibliografii; warto tu może jednak wymienić pierwszy polski przekład calego traktatu $O$ państwie Bożym w opracowaniu W. Kubickiego ${ }^{80}$, a także pierwsze thumaczenie starożytnego $\dot{Z y w o t a ~ s ́ w . ~}$ Augustyna autorstwa Possydiusza w opracowaniu J. Ujdy ${ }^{81}$. Również w drugiej polskiej serii wydawniczej, wszczętej w 1967 r. na Akademii Teologii Katolickiej w Warszawie Pisma Starochrześcijańskich Pisarzy, bardzo licznie prezentowane są przekłady pism augustyńskich: na 63 opublikowane już tomy św. Augustynowi poświęcono aż 21, głównie dzięki tłumaczeniom Jana Sulowskiego $^{82}$. Jest on także często obecny w publikacjach Wydawnictwa PAX; wśród wydanych od 1952 r. ok. 30 tomów poświęconych patrystyce, figuruje 9 przekładów $^{83}$ i 20 innych samodzielnych augustyńskich publikacji.

W oparciu o wyżej wymienione przekłady i oryginalne teksty św. Augustyna starano się również odczytać jego myśl, co się wyraziło w różnego rodzaju opracowaniach. We wspomnianej na wstępie bibliografii $S$ w. Augustyn w polskich studiach, opublikowanej w 44-45 tomie „Vox Patrum”, wymienionych jest ponad 600 polskich opracowań augustyńskich, w tym ponad 60 pozycji książkowych. Wśród zaś prac dyplomowych, związanych z postacią Biskupa Hippony, naliczyliśmy 6 habilitacji, 13 doktoratów, 11 licencjatów i 287 prac magisterskich.

confesse dans ses Confessions, „Eos” 30 (1927) 379-400; tenże, De eis, quae in Augustini „Confessionibus" non sint confessoria, PT 11 (1930) 399-413.

77 Poznań 1929.

${ }^{78}$ Por. Wyznania, POK 9; Pisma katechetyczne, POK 10; Państwo Boże, POK 11-13; O Trójcy Swiętej, POK 25; Traktaty o lasce. Easka - wiara-przeznaczenie, POK 27.

${ }^{79}$ Por. W. Eborowicz, Les études contemporaines sur St. Augustin en Pologne, w: Augustinus Magister. Actes de Congrès International Augustinien, t. 2, Paris 1954, 1139-1153, tłum. K. Domagalski: Badania nad św. Augustynem w Polsce od 1918 roku, „Życie Katolickie” 7 (1988) nr 9, 58-70; tenże, Polska bibliografia św. Augustyna (1918-1954), „Kuźnica Kapłańska” 2 (1954) nr 22, $24-29$

${ }^{80}$ Z łaciny tłum. oraz wstępem i komentarzem opatrzył W. Kubicki, Poznań 1930, 1934, 1937, POK 11-13.

${ }^{81}$ Por. tamze POK 11, Poznań 1930, s. XVII-XCV; lub oddzielnie: Poznań 1930, ss. XXIII +63 .

${ }^{82}$ Por. następujące tomy PSP: XII, XV 1-2, XIX 1-3, XXII, XXV, XXXVII-XXII, XLVIXLVI, L, LIV, LV, LVI.

${ }^{83}$ Wśród nich 4 tomy Dialogów filozoficznych, Warszawa 1953-1954 oraz 2 monumentalne tomy O państwie Bożym w przekładzie W. Kornatowskiego, Warszawa 1977. 
W tym nicmałym, jak widać, naukowym trudzie odczytywania myśli urodzonego 1650 lat temu autora, do najbardziej zasłużonych badaczy (zależnie od ilości ich augustyńskich publikacji) należą: ks. Wacław Eborowicz, ks. Augustyn Eckmann, ks. Jan Czuj, ks. Stanisław Kowalczyk, Jan Sulowski, ks. Józef Pastuszka i ks. Jan Edling. Niektórzy z nich (ks. W. Eborowicz, ks. S. Kowalczyk, ks. S. Grabowski, ks. R. Paciorkowski, ks. A. Słomkowski) dzielili się owocami swych dociekań naukowych także za granicą, publikując je również w językach obcych. Podczas tych docickań Polaków interesowaly nie tylko teologia i filozofia, ale i jego spojrzenie na sprawy społeczne, sprawy małżeństwa, rodziny i wychowania, problem ascezy i dziewictwa, a takze jego historiografia.

\section{III}

Recepcji św. Augustyna trzeba dla całości problemu szukać także w innych, nienaukowych dziedzinach kultury polskiej, jak w architekturze, ikonografii, literaturze, kulcie i zwyczajach; poszukiwań tych jednak dotąd nikt u nas nie podejmowal, a byłyby one zapewne ciekawe. W Polsce mamy aktualnie 13 kościołów parafialnych pod wezwaniem św. Augustyna, a geneza ich tytułów była najczęściej przypadkowa - zależała niekiedy od imion fundatorów lub pozostaje niewyjaśniona. Rzecz ciekawa, że żadnego $z$ nich nie zbudowali opierający się na jego regule sprowadzeni do Polski w 2 poł. XIV wieku augustianie $^{84}$. Są to nie tylko kościoły i parafie średniowieczne, ale powstałe także w XX wieku, rozrzucone po całej Polsce. A oto ich alfabetyczny wykaz:

1. Babiak (diec. warmińska) - kościół pod wezwaniem św. Augustyna i św. Anny zbudowany w 2 poł. XVI wieku, konsekrowany 29 VIII 1580 r. przez bpa Marcina Kromera, rozbudowywany w 1864 r., gruntownie przebudowywany w latach 1986-1997.

2. Borucin (diec. opolska) - kościół murowany neogotycki, wybudowany w 1906 r., konsekrowany 22 VII 1908 roku przez abpa P. Bauera z Ołomuńca; parafia z żywymi tradycjami morawskimi założona w 1906 r., należała do 1923 r. do diecezji ołomunieckiej w Czechosłowacji, od 1923 zaś roku do dekanatu Kietrz w diecezji opolskiej.

3. Bratoszewice (diec. tódzka) - kościół murowany w stylu gotyckim z końca XV wieku, parafia erygowana przez Jana Łaskiego w 1525 r.; kościół spalony podczas najazdu szwedzkiego został odbudowany w 1696 r., gruntownie przebudowany w latach 1898-1901 w stylu neogotyckim: jednonawowy, z krótkim

${ }^{84} \mathrm{O}$ augustianach również polskich zob. J. Kowalczyk, EK I 1073-1079; H.E. Wyczawski. Augustiańska parafia w Radomyślu nad Sanem, Warszawa 1964; W. Łuszczkiewicz, Kościót p.w. Katarzyny z klasztorem ojców augustianów, Kraków 1898; R. Zdziarska, Kościót i klasztor augustianów w Warszawie. Dzieje architektury od XIV do XVIII wieku, ze szczególnym uwzględnieniem okresu baroku, Warszawa 1969 (mps BKUL). 
półkolistym prezbiterium i dwoma bocznymi neogotyckimi kaplicami; w neogotyckim ołtarzu głównym obraz św. Augustyna z XVIII wieku.

4. Ciechanowice (diec. legnicka) - kościól wspominany już w 1385 r., a obecny wybudowany w $1577 \mathrm{r}$. w stylu gotycko-renesansowym, w latach 1957-1968 gruntownie remontowany; parafia erygowana w 1976 r. z dotychczasowej parafii Marciszów.

5. Czapury (diec. poznańska) - kościół w budowie, w oltarzu tymczasowej kaplicy statua św. Augustyna; parafia erygowana w 1999 roku.

6. Jamy Wielkie (diec. tarnowska) - kościół drewniany, zbudowany w XVIII wieku w Wadowicach Górnych, a w 1916 r. zakupiony i przeniesiony do Jam Wielkich, poświęcony 28 VIII 1916 r. przez bpa Leona Wałęgę, odnawiany w $1961 \mathrm{r}$;; parafia erygowana $10 \mathrm{~V} 1925$ r.; kościół jednonawowy z sygnaturką i dobudowanym przedsionkiem, konstrukcji zrębowej, szalowany, $\mathrm{z}$ węższym prezbiterium zamkniętym trójbocznie, $\mathrm{z}$ jedną boczną kaplicą zamkniętą trójbocznie i dwoma kruchtami (ryc. 57); we wnętrzu pozorne sklepienie kolebkowe o łuku obniżonym oraz stropy płaskie: wewnątrz trzy ołtarze późnobarokowe z XVIII wieku, przeniesione wraz z kościołem z Wadowic Górnych: w ołtarzu głównym obraz namalowany przez ludowego artystę przedstawia św. Augustyna w postaci klęczącego kapłana w ornacie przed siedząca Matką Bożą z Dzieciątkiem (ryc. 58-59), którym prawą ręką podaje serce przebijane strzała przez Jezusa (zob. ryciny na końcu artykułu).

7. Kostów (diec. kaliska) - kościół istniejący już w średniowieczu, ok. poł. XVI wieku przejęty został przez protestantów; obecny - murowany w latach 1909-1911 w stylu neobarokowym, restaurowany w 1955 r.; parafia erygowana w 1927 roku.

8. Kurozwęki (diec. sandomierska) - kościół wybudowany w 1157 r.; ten pierwotny kościółek stanowi prezbiterium dobudowanej w $1483 \mathrm{r}$. nawy; parafia erygowana w 1809 roku.

9. Lipiny Śląskic (diec. katowicka) - kościół w niemieckim stylu neogotyckim, zbudowany w 1872 r.; parafia erygowana w 1888 r. z parafii św. Barbary w Chorzowie; na terenie parafii kaplica św. Moniki w domu Złotej Jesieni.

10. Różanka nad Bugiem (diec. siedlecka) - pierwotny kościól uposażony przy erygowanej parafii w 1757 r. przez Antoniego Pocieja, zamieniony zostal na cerkiew; obecny murowany, ale nie konsekrowany, został wybudowany w stylu neogotyckim w 1908 r. kosztem Augusta hr. Zamoyskiego i wiernych; parafia katolicka wznowiona została w 1919 r. przez bpa H. Przeździeckiego.

11. Warszawa - Muranów na Nowolipkach (diec. warszawska) - kościól zbudowany w latach 1891-1896 w stylu neoromańskim z cegły, trzynawowy, bazylikowy z trójkątnie zamkniętym prezbiterium, i wysoką $(70 \mathrm{~m})$ wieżą zwieńczoną krzyżem na dużej kuli (ryc. 60), wg E. Cichockiego przez ks. Karola Czajkowskiego z fundacji hrabiny Aleksandry Potockiej, która w ten sposób postanowiła upamiętnić zmarłego męża Augusta Potockiego; konsekrowany 
5 IX 1905 r. przez bpa Kazimierza Ruszkiewicza, był początkowo kościołem filialnym parafii Narodzenia NMP na Lesznie; po erygowaniu parafii w 1905 r. stał się kościołem parafialnym. W czasie wojny zamknięty i przeznaczony najpierw na magazyn zrabowanych mebli, a potem na stajnię. Podczas powstania warszawskiego na jego wieży był punkt obserwacyjny $i$ gniazdo niemieckiej broni maszynowej, zniszczone przez żołnierzy batalionu „Zośka”. Po powstaniu Niemcy podpalili kościół, ale nie zdążyli go wysadzić, tak że wkrótce potem przynajmniej częściowo go odbudowano i już w roku 1947 oddano do użytku wiernych. W ołtarzu głównym wg projektu Józefa Piusa Dziekońskiego umieszczono rzeźbę wloskiego artysty Ferdynanda Palla, przedstawiającą św. Rodzinę. W nawach bocznych umieszczono 6 ołtarzy: we wschodniej znajduje się ołtarz Patrona kościoła - św. Augustyna z jego obrazem anonimowego autora, przedstawiającym go w postaci stojącego biskupa z pastorałem i paliuszem oraz unoszącym się nad nim aniołem $\mathrm{z}$ wyciągniętą ręką (ryc. 61). Ufundowana zaś do tej świątyni przez F.A. Sobańskich rzeźba Ferdynanda Palla, przedstawiająca św. Augustyna ze św. Moniką, znajduje się dziś w kościele NMP na ulicy Przyrynek. Z okazji 25-lecia pontyfikatu Jana Pawła II, za staraniem obecnego niezmordowanego proboszcza, dziekana i prałata ks. Walentego Królaka, ufundowano do przykościelnej wieży 4 nowe dzwony, $\mathrm{z}$ których dwa poświęcono Biskupowi Hippony: większy $(220 \mathrm{~kg}) \mathrm{z}$ podpisem i wizerunkiem św. Augustyna (ryc. 62), wzorowanym na obrazie w bocznym oltarzu, posiada cytat z Wyznań: "Przyjdź, Panie, i porusz nasze serca”, oraz mniejszy $(140 \mathrm{~kg})$ z napisem i wizerunkiem św. Moniki (ryc. 63) i napisem: „Panie, niech nie zginie żaden syn matczynych łez" (zdjęcia kościoła, ołtarza Patrona, oraz dzwonów zob. w aneksie).

12. Wrocław OO. Kapucyni (diec. wrocławska) - pierwotny kościół p.w. św. Augustyna został zbombardowany w 1941 r.; erygowaną po wojnie w 1946 r. parafię objęli troską duszpasterską OO. Kapucyni z prowincji krakowskiej. Po odbudowaniu zniszczonego w czasie wojny zbudowanego w latach 1896-1898 kościoła protestanckiego p.w. św. Jana Chrzciciela, przeniesiono w 1949 r. do niego parafię św. Augustyna.

13. Budowo-Złocieniec - to wojskowa izba modlitwy p.w. św. Augustyna w prowizorycznej kaplicy klubu żołnierskiego, należąca do Pomorskiego Okręgu Wojskowego na terenie diecezji koszalińsko-kołobrzeskiej; parafię erygował 13 VIII 1983 r. biskup polowy Sławoj Leszek Głódź, w grudniu zaś 1998 r. rozpoczęto budowę nowego kościoła garnizonowego.

W każdym z wyżej wymienionych kościołów są zapewne obrazy lub statuy św. Augustyna, śpiewa się ku jego czci specjalnie układane pieśni lub organizuje nabożeństwa, a pod koniec sierpnia, w dniu jego wspomnienia, urządza się uroczyste odpusty.

Jeśli chodzi o ikonografię św. Augustyna, to wiadomo, że najstarszy jego portret zachował się na ściennym fresku z czasów Grzegorza Wielkiego 
w dawnej Bibliotece Laterańskiej, a później na dyptychu Boecjusza z ok. 650 r. obok św. Hieronima i Grzegorza Wielkiego w Muzeum Miejskim w Brescii ${ }^{85}$. Później, zwłaszcza od XIV wieku, mnożą się obrazy św. Augustyna, ujmowane często w cykle, przedstawiające całe jego życie; zebrali je aż w 4 opasłych tomach Jeanne i Pierre Courcelle'owie ${ }^{86}$, nie umieszczając jednak w nich żadnego polskiego śladu. W dobie Renesansu, przedstawiano go zarówno w rzeźbie jak i w malarstwie razem z czterema innymi Wielkimi Doktorami Kościoła Zachodniego (obok Ambrożego, Hieronima i Grzegorza Wielkiego).

W polskim malarstwie religijnym, poza grupą czterech Wielkich Doktorów Kościoła, św. Augustyn przedstawiamy jest stosunkowo rzadko, chyba że w kościołach mu poświęconych; jednym $\mathrm{z}$ najstarszych jest tu witraż z 1 . poł. XIV wieku w kościele OO. Dominikanów w Krakowie. Do wyjątkowych jego przedstawień należy jego postać $\mathrm{z}$ orłem, symbolem św. Jana Ewangelisty, w jednej z kwater oltarza $z$ Mikuszowic z ok. 1370 r. w muzeum w Krakowie. Na uwagę zasługuje też obraz św. Augustyna w Klasztorze Jasnogórskim autorstwa brata Tyburcego Nowakowicza z 1622 roku $^{87}$. Sa to jednak bardzo nikłe przyczynki do przedstawienia polskiej ikonografii św. Augustyna, która nadal czeka na opracowanie.

Także w literaturze polskiej trudno znaleźć powieść, dramat lub większy poemat, których głównym bohaterem byłby Biskup Hippony. Również w zwyczajach polskich św. Augustyn nie jest zbyt popularny w porównaniu z innymi starożytnymi świętymi (np. św. Mikołajem). Choć imię to znane jest w Polsce od XIII wieku jako Augustyn lub częściej jako August, albo w formie spolonizowanej - Jagustyn, to nie jest zbyt często noszone (nosił je np. obrońca Częstochowy Augustyn Kordecki (1603-1673), a wiąże się z nim jedno z nielicznych przyslów: „Na świętego Augustyna, orka dobrze się poczyna”.

\section{$* * *$}

W ten oto sposób omówiliśmy szkicowo problem recepcji św. Augustyna w kulturze polskiej na dwóch plaszczyznach: naukowej i nienaukowej. O ile na płaszczyźnie naukowej recepcja ta nie przedstawia się najgorzej, bo mamy już sporo przekładów jego pism, niemało różnych syntez jego myśli i stosunkowo dużo prac dyplomowych na jego temat, to na płaszczyźnie nienaukowej jest jeszcze bardzo wiele do zrobienia. Przyglądając się bliżej pierwszej, łatwo

${ }^{85}$ Por. P. Styger, Wizerunki św. Augustyna ma podstawie najstarszych portretów $i$ dokumentów, w: Studia Augustyńskie, Warszawa 1931, 13-24.

${ }^{86}$ Por. Iconographie de Saint Augustin, t. 1: Les cycles du XIV siècle, Paris 1965; t. 2: Les cycles du XV siècle, Paris 1969; t. 3: Les cycles du XVI et XVII siècles, Paris 1972; t. 4: XVIII siècle: Allemand, Paris 1980.

${ }^{87}$ Por. K. Bartoszewski, EK I 1113-1115 (Ikonografia św. Augustyna); Historia sztuki polskiej, red. T. Dobrowolski - W. Tatarkiewicz, I, Kraków 1962; 1965² I 341-342. 
zauważyć, że jeszcze spora część twórczości Biskupa Hippony oczekuje na przyswojenie polskiemu czytelnikowi: warto by przetłumaczyć resztę jego mów i listów, oraz tak ważne traktaty jak: De baptismo, De peccatorum meritis, Contra Faustum Manichaeum, De anima et eius origine, resztę jego komentarzy biblijnych przynajmniej w wyborze i inne. W drugiej zaś dziedzinie trzeba by opracować prawie dotąd nietkniętą (podobnie jak innych Ojców Kościoła) ikonografię św. Augustyna, zebrać pieśni ku jego czci oraz omówić ich genezę i wpływ, wychwycić dokładniej jego obecność w literaturze i zwyczajach polskich. Dla pewnego zilustrowania tej tematyki wybraliśmy dwa różne kościoły p.w. św. Augustyna: jeden wiejski, ubogi, drewniany z XVIII wieku w Jamach Wielkich, drugi ze stolicy, bogaty, murowany z końca XIX wieku; ukazujemy ołtarze $z$ obrazami ich Patrona, pamiątki z nim związane, oraz przytaczamy teksty pieśni ku jego czci w nich śpiewane. Zarówno bowiem przekłady pism i rozprawy naukowe w oparciu o nie napisane, jak i ikonografia, zwyczaje i wszelkie przejawy kultu składają się na pełny obraz obecności żyjącego przed 1600 lat św. Biskupa Augustyna w kulturze polskiej.

\section{DE RECEPTIONE S. AUGUSTINI IN CULTURA POLONORUM}

\section{(Argumentum)}

Hac in brevi dissertatione, quae tribus partibus constat, praesentia S. Augustini in cultura Polonorum praestatur. In parte priore actuales translationes operum S. Augustini in linguam Polonorum generatim explanantur, in altera autem atque longissima huiusmodi translationes et antiquissima studia Augustiniana Polonorum saeculis XII-XIX adducuntur, in postrema denique receptio Episcopi Hipponensis in Polonorum iconographia, ecclesiis S. Augustino dedicatis, canticis augustinianis, necnon litteris ac moribus generaliter exponitur. 
ILUSTRACJE 


\section{WYKAZ ILUSTRACJI}

B. Iwaszkiewicz-Wronikowska - Gtoszenie stowa. Kilka uwag na temat motywn ksiegi w ikonografii worzesnochrzescijańskiej. ilustracje $1-23$ R. Bulas - Grzegorz. Wielki w anglosaskiej Brytanii i celtyckiej Irlandii ..... ilustracje 2442

A. Stępniewska - Sylwia - matka papieža Grzegorza Wielkiego ilustracje 43-49

R. Wierna - Obraz su. Mikotaja Cudotwórcy z. Opola Podedwórza .......... ilustracja 50 P. Szkołut - Sceny meczeństwa i ocalenia w póżnoantycznej sžtuce synagogalnej ilustracje 51-56

ks. S. Longosz - Recepcja sum. Augustyna w kulturze polskiej ilustracje 57-63 


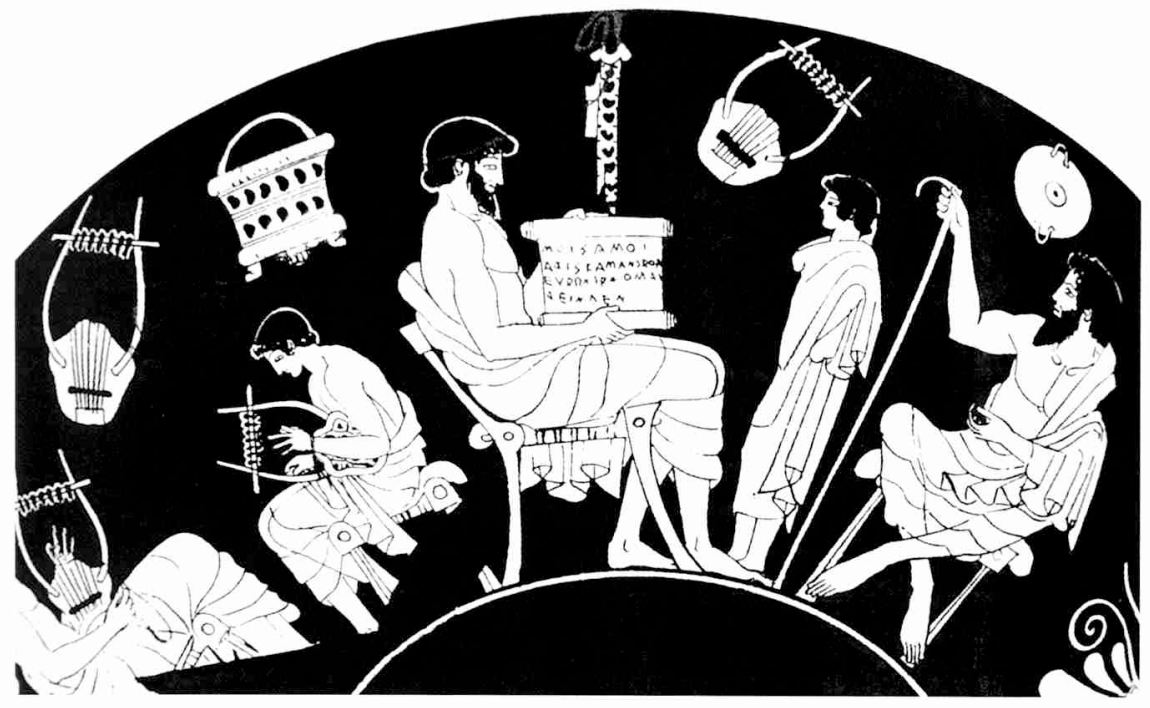

1. Fragment dekoracji wazy Durisa z pocz. V wicku przed Chr. (za: Malowidło na wazie Durisa (A. Furtwängler, K. Reichhold, Griechische Vasenmalerei, 1900-1932, tabl. 136).

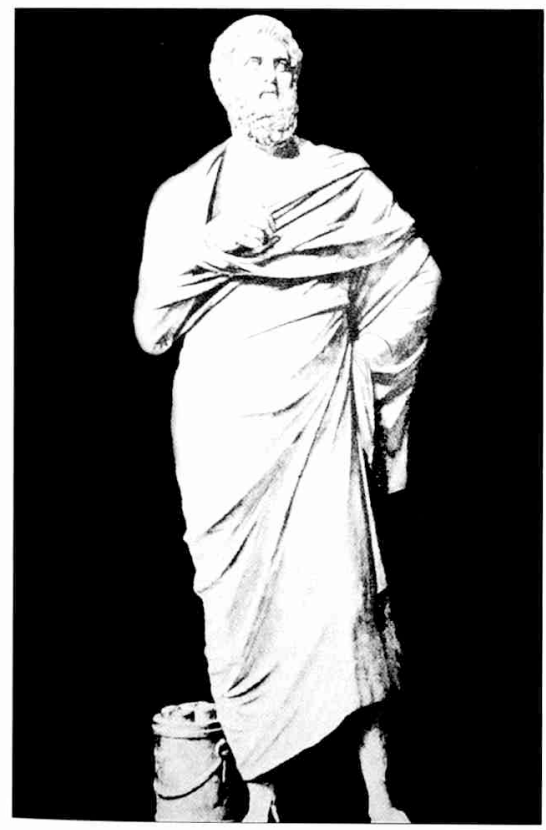

2. Posąg grecki z IV wieku (za: M. Nowicka, Twarze antyku, Warszawa 2000, il. 12)

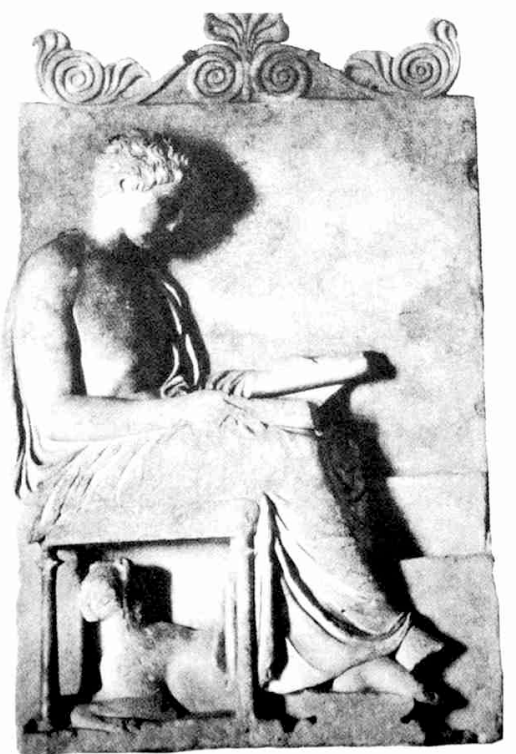

3. Grecka stela nagrobna z końca $\mathrm{V}$ wieku przed Chr. (za: praca zbiorowa, W dawnych Atenach, Wrocław - Warszawa - Kraków - Gdańsk 1971, il. na s. 198) 


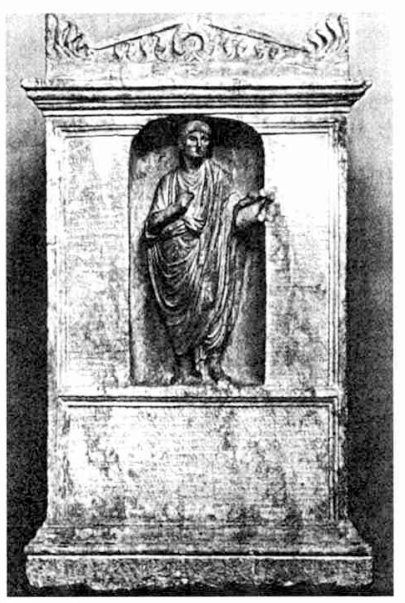

4. Stela nagrobna mlodocianego

poety Q. Sulpiciusa Maximusa (za:

H. Blanck, Das Buch in der Antike,

München 1992, il. 45

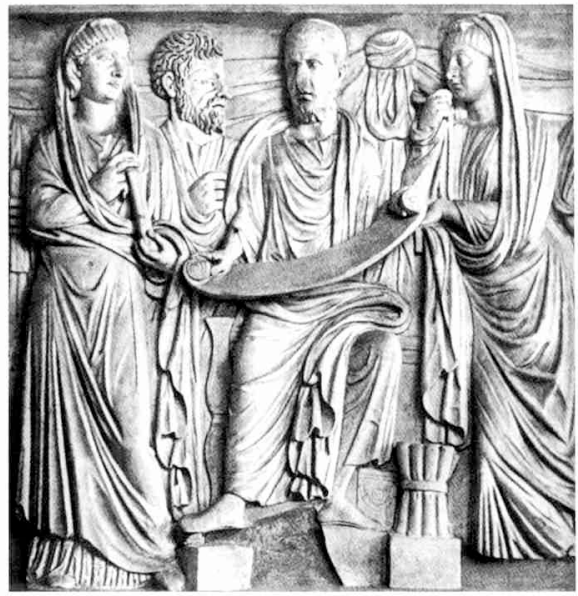

6. Fragm. relicfu z tzw. Sarkofagu Plotwna (za:

A. Grabar, Le premier art chrétien, 200-395, Paris 1966, il. 50)

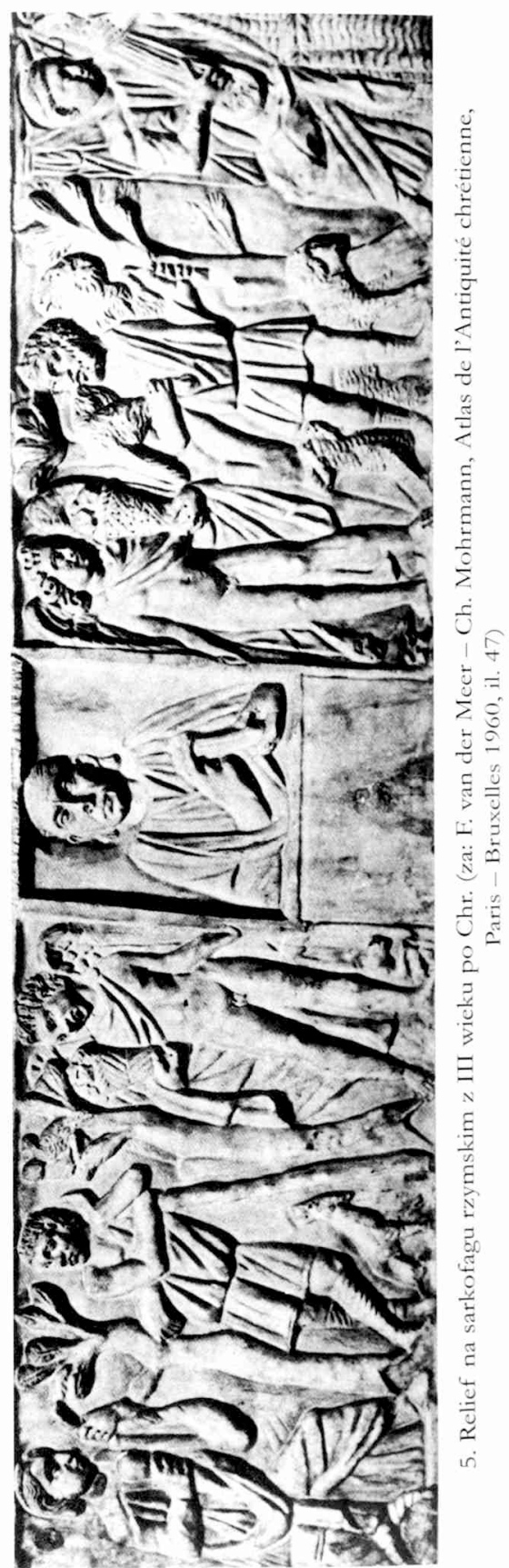




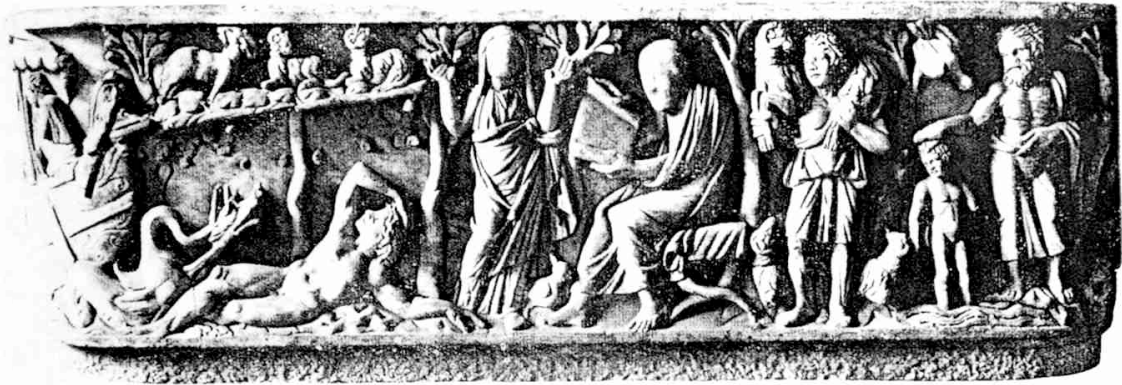

7. Sarkofag z kościoła S. Maria Antica w Rzymie (za: A. Grabar, Le premier art chrétien, 200-395, Paris 1966, il. 131)

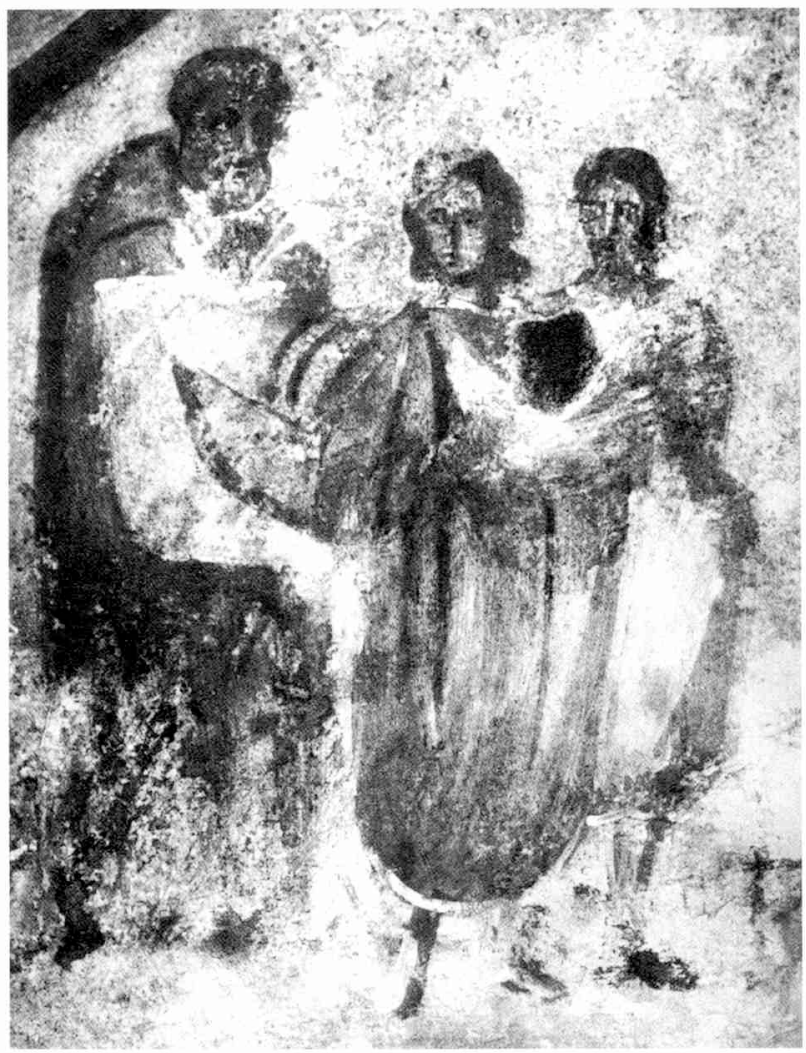

8. Fragm. malowidła z tzw. Cubiculum Velatio w rzymskiej katakumbie Pryscylli (za: A. Grabar, Le premier art chrétien, 200-395, Paris 1966, il. 112 ) 


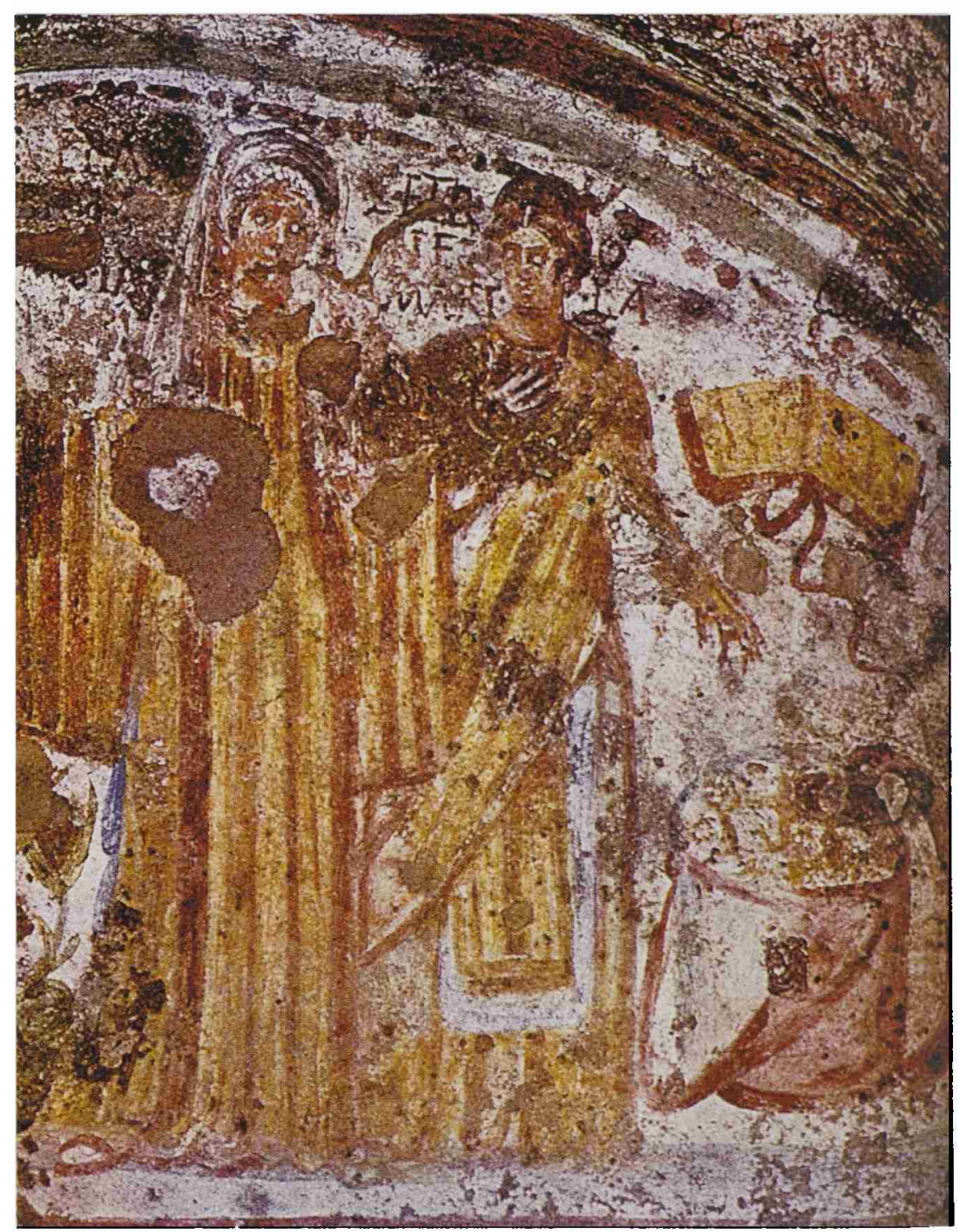

9. Fragm. malowidla $z$ tzw. Arcosolium Wenerandy w rzumskiej katakumbie Domicylli (za: P. Du Bourguet, Art paléochrétien, Paris 1970, s. 153) 


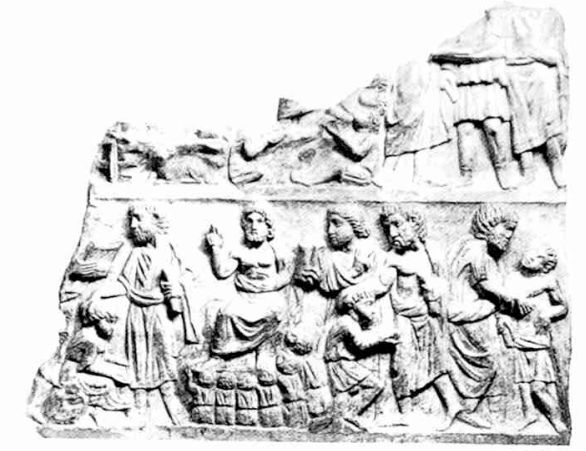

10. Jeden z tzw. Polichromowanych Fragmenów (za: B. Brenk, Spätantike und frühes Christentum, Frankfurt a. M. - Berlin - Wien 1977, il. $70 \mathrm{~b}$

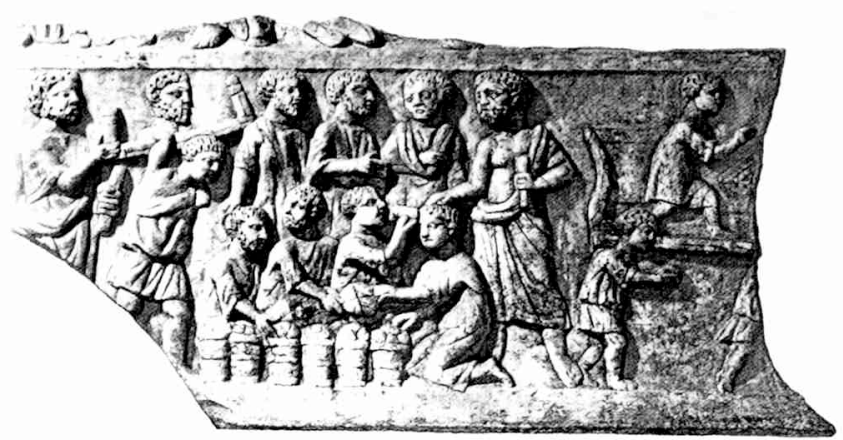

11. Jeden $z$ tzw. Polichromowanych Fragmenów (za: B. Brenk, Spätantike und frühes Christentum, Frankfurt a. M. - Berlin - Wien 1977, il. 70 a

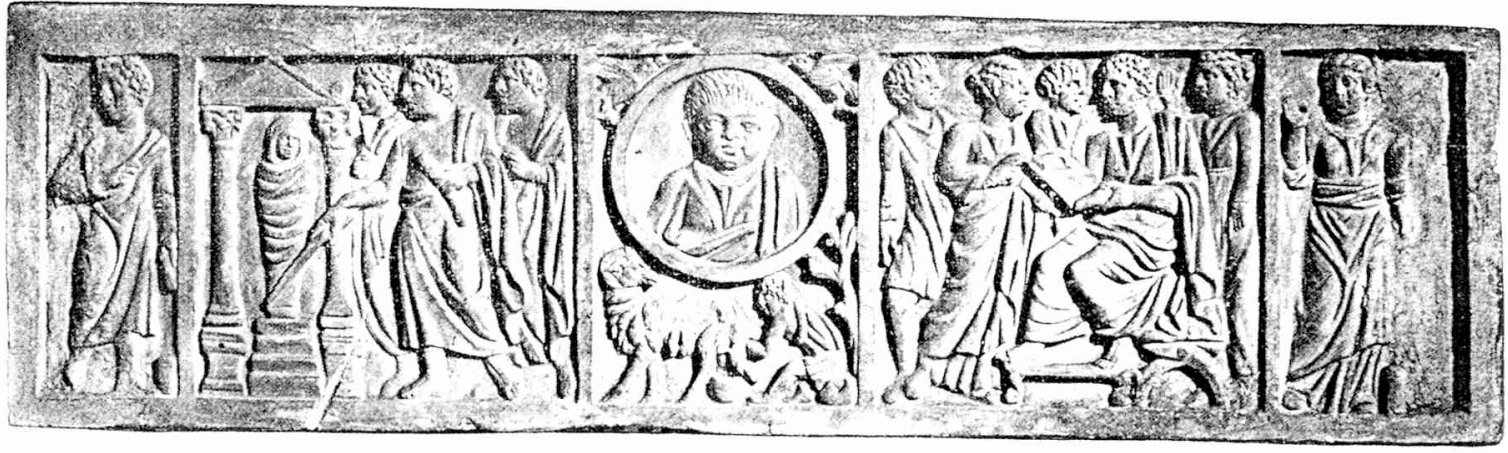

12. Relief na płycie z Muzeum Kapitolińskiego (za: P. Testini, Le catacombe e gli antichi cimiteri cristiani in Roma, Bologna 1966, il. 209) 


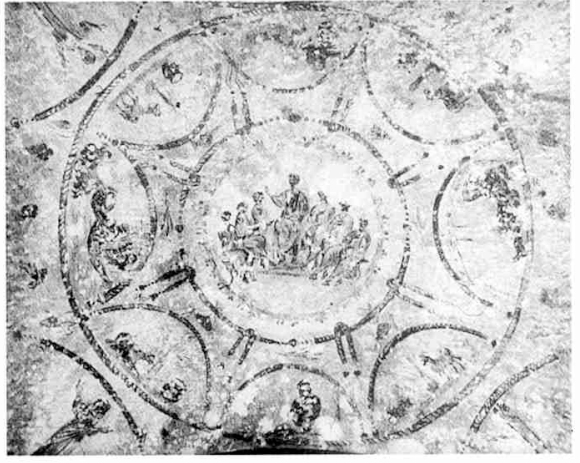

13. Malowidło na suficie Cubiculum 58 w rzymskiej katakumbic Marcellina i Piotra (za: J. Kollwitz, Die Malerei der konstantinische Zeit, w: Akten des VII Internationalen Kongresses der Christliche Archäologie, Trier 5-11 September 1965, Berlin - Città del Vaticano 1969 , tabl. VI, 9)

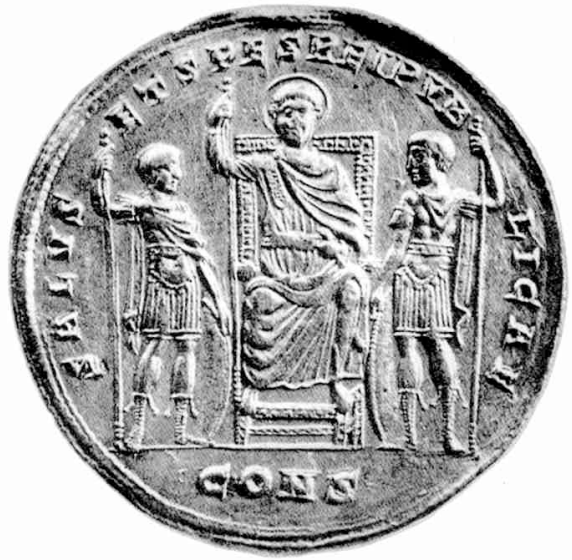

15. Medalion z IV wieku z przedstawieniem cesarza rzymskiego na tronie (za: A. Grabar, Le premier art chrétien, 200-395, Paris 1966 , il. 213)

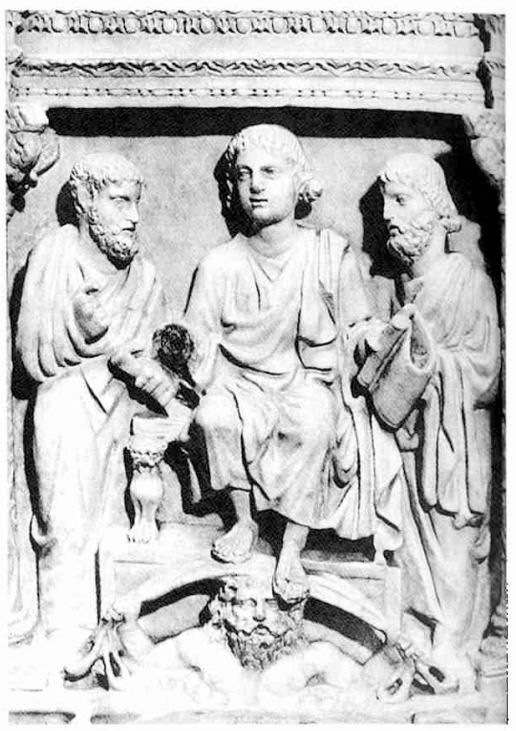

14. Fragm. reliefu na sarkofagu Juniusa Bassusa (za: A. Grabar, Le premier art chrétien, 200-395, Paris 1966, il. 41)

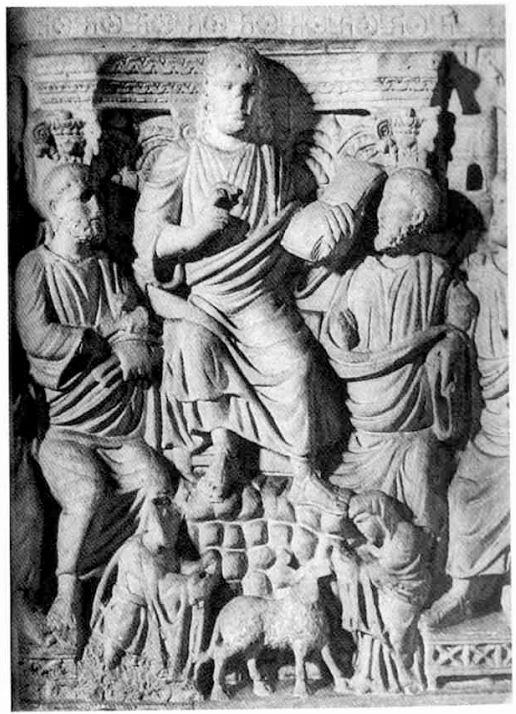

16. Fragm. reliefu na tzw. sarkofagu Stylichona (fot. autorki) 


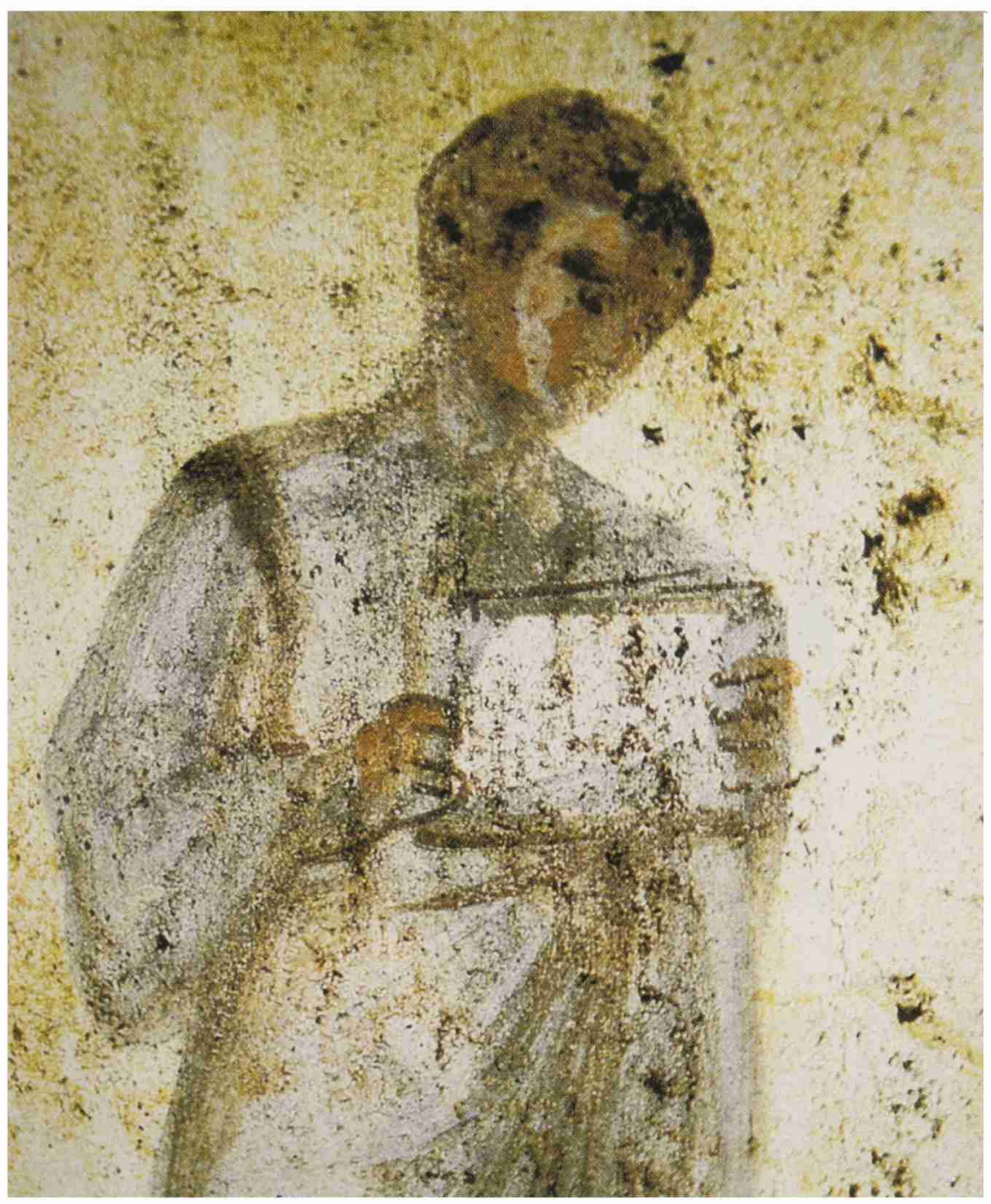

17. Fragm. malowidła z Cubiculum 65 rzymskiej katakumby Marcellina i Piotra J.G. Deckers - H. R. Seeliger - G. Mietke, Die Katakombe „Santi Marcellino e Pietro”. Repertorium der Malereien, Münster 1987, tabl. 46a) 


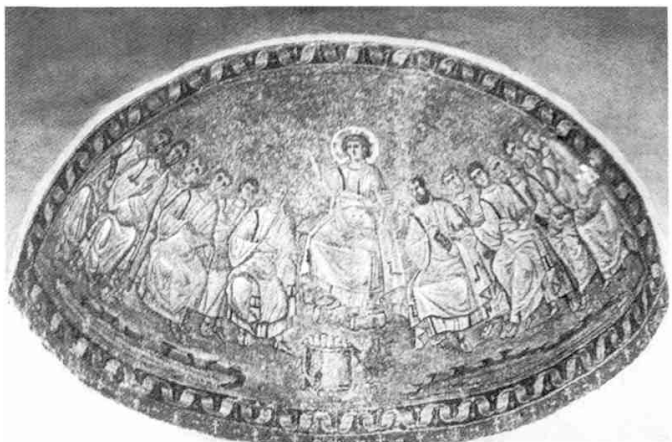

18. Mozaika z kaplicy San Aquilino Bazyliki San Lorenzo Maggiore w Mediolanie (za: G. Traversi, Architettura paleocristiana Milanese, Milano 1964, tabl. II)

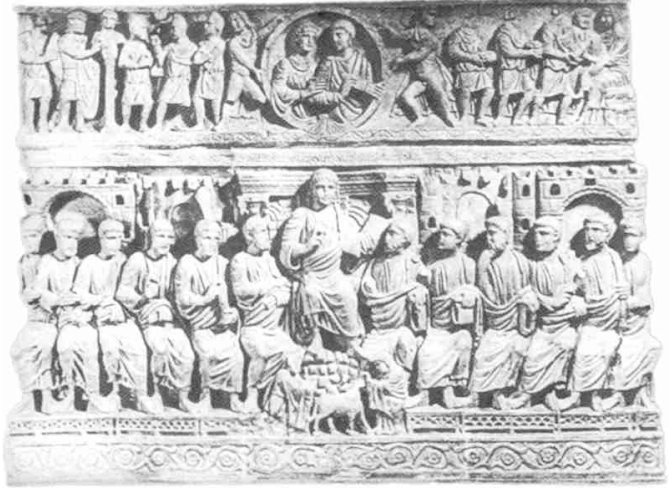

19. Tzw. Sarkofag Stylichona (za: F. van der Meer - Ch. Mohrmann, Atlas de l'Antiquité chrétienne, Paris - Bruxelles 1960, il. 527)

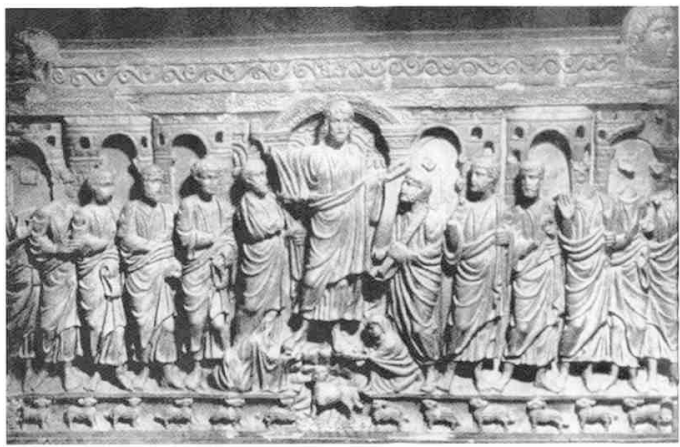

20. Tzw. Sarkofag Stylichona (za: H. P. L’Orange, Art Forms and civic Life, Princeton 1965, il. 9) 


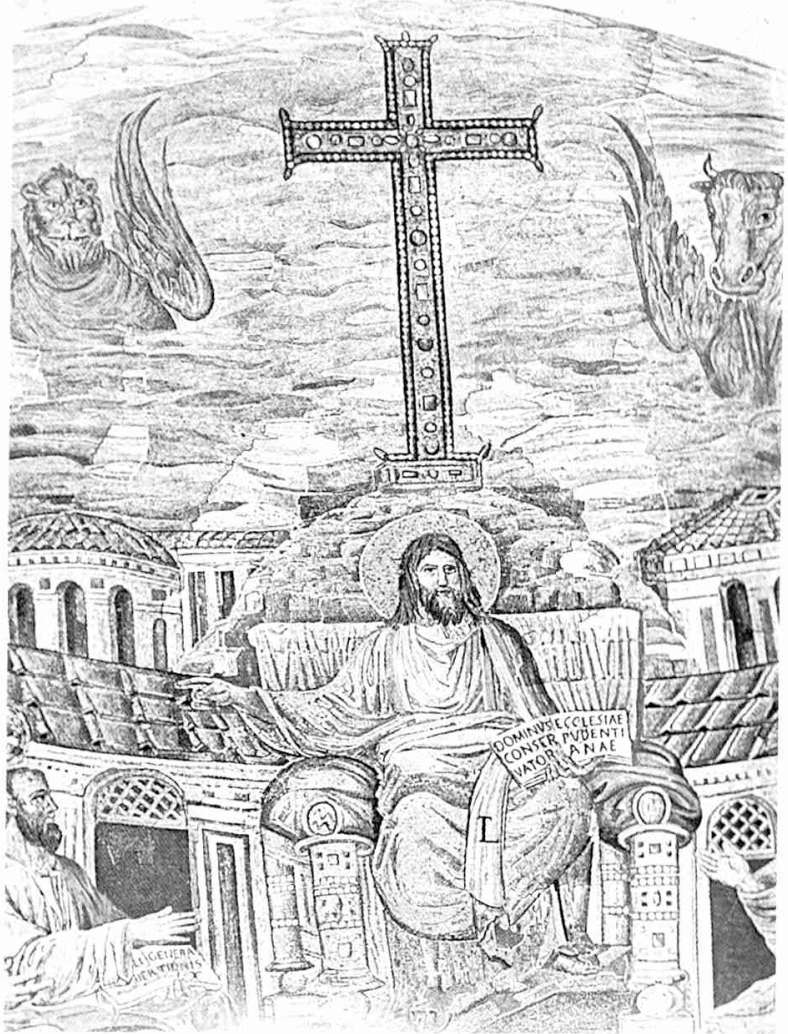

21. Fragm. Mozaiki z absydy kościoła S. Pudenziana w Rzymie (za: F. van der Meer - Ch. Mohrmann, Atlas de l'Antiquité chrétienne, Paris - Bruxelles 1960, il. 320)

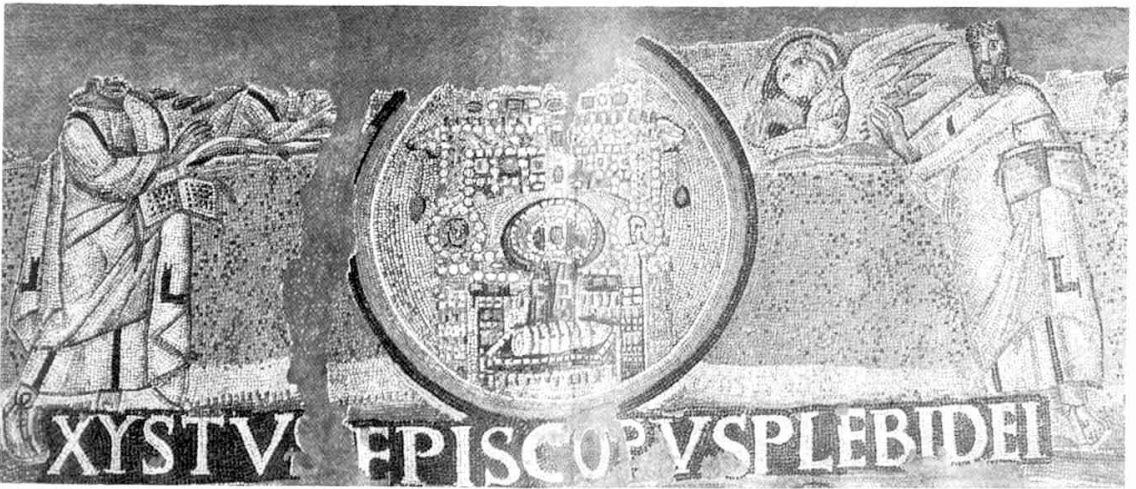

22. Fragm. Mozaiki na Luku Triumfalnym w rzymskiej Bazylice S. Maria Maggiore (zdjęcie ze zbiorów Katedry Historii Sztuki Starożytnej i Wczesnochrześcijańskiej KUI.) 


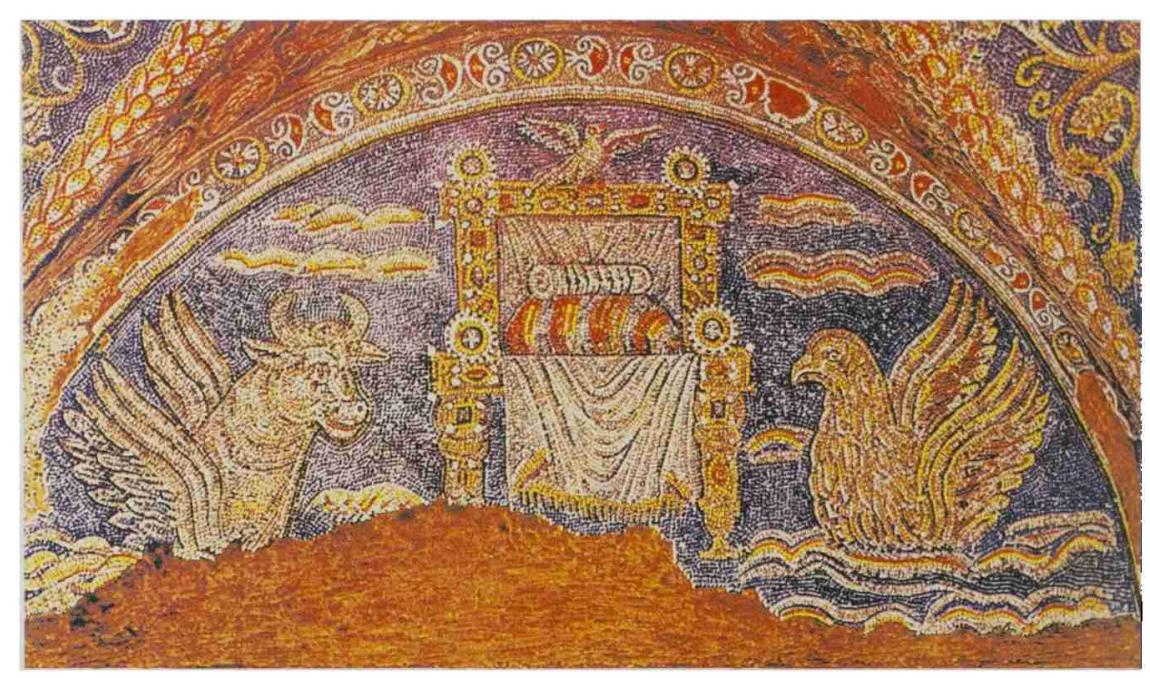

23. Mozaika w absydzie kaplicy w S. Prisco w Capui (J. Wilpert - W.N. Schumacher, Die römischen Mosaiken der kirchlichen Bauten von IV-XIII Jahrhundert, Freiburg 1976, tabl. 84) 


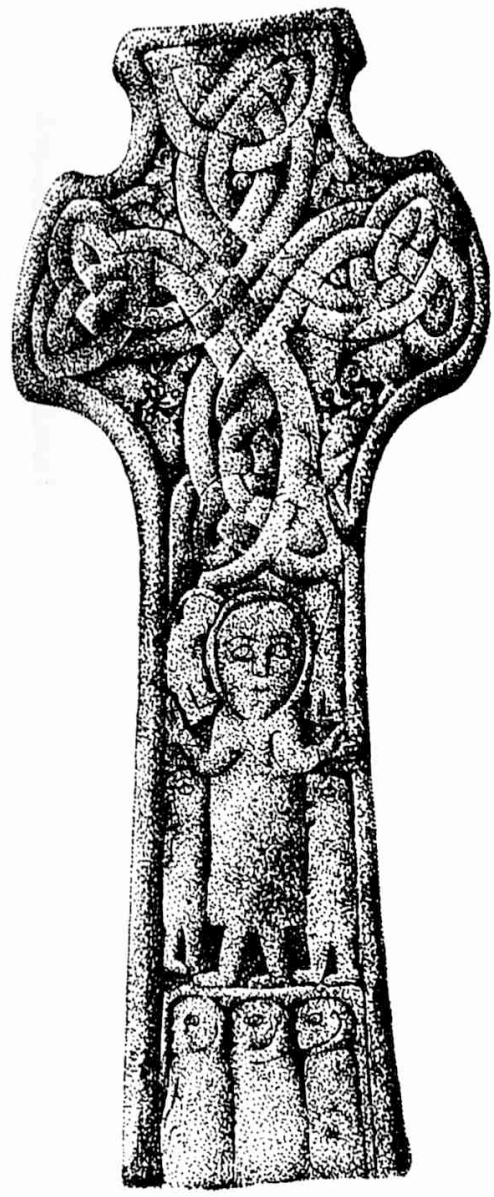

24. Krzyż z Carndonagh (hr. Donegal), strona wschodnia, Ukrzyżowanie?

Wedlug: P. Harbison, Irish High Crosses with the figure sculpiures explained, Drogheda $1994,26$.

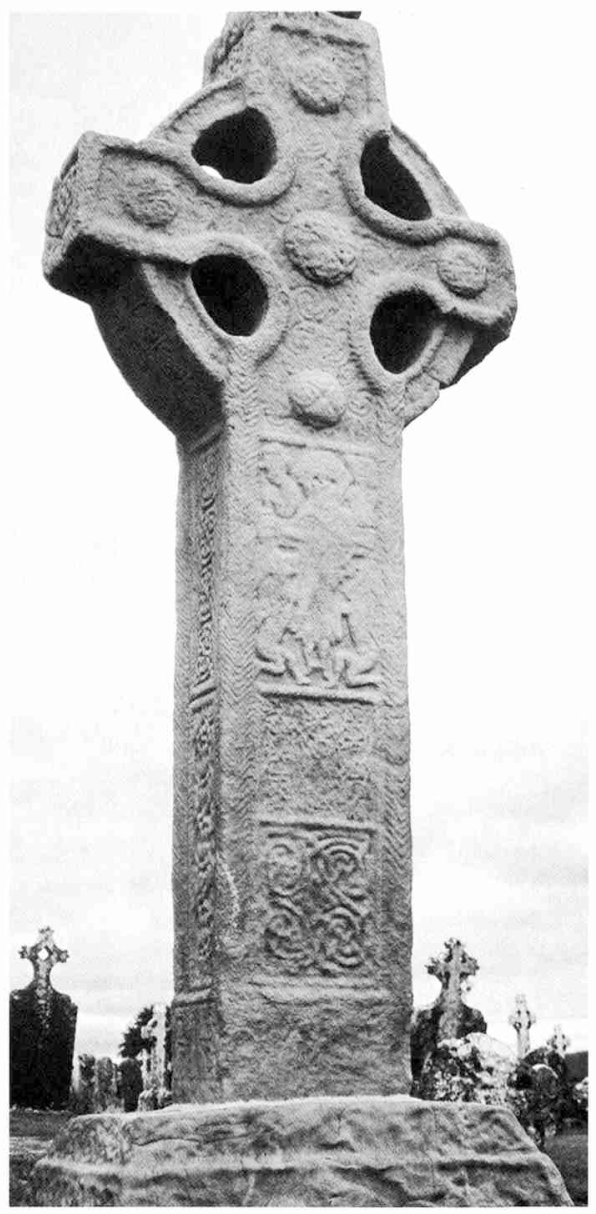

25. Krzyz Poludniowy z Clonmacnois

(hr. Offaly), strona wschodnia. Na bazie polowanie, na trzonie Ukrzyżowanic. Według: H. Richardson - J. Scarry, An Introduction to Irish High Crosses, Dublin 1990, 80, Plate 60. 


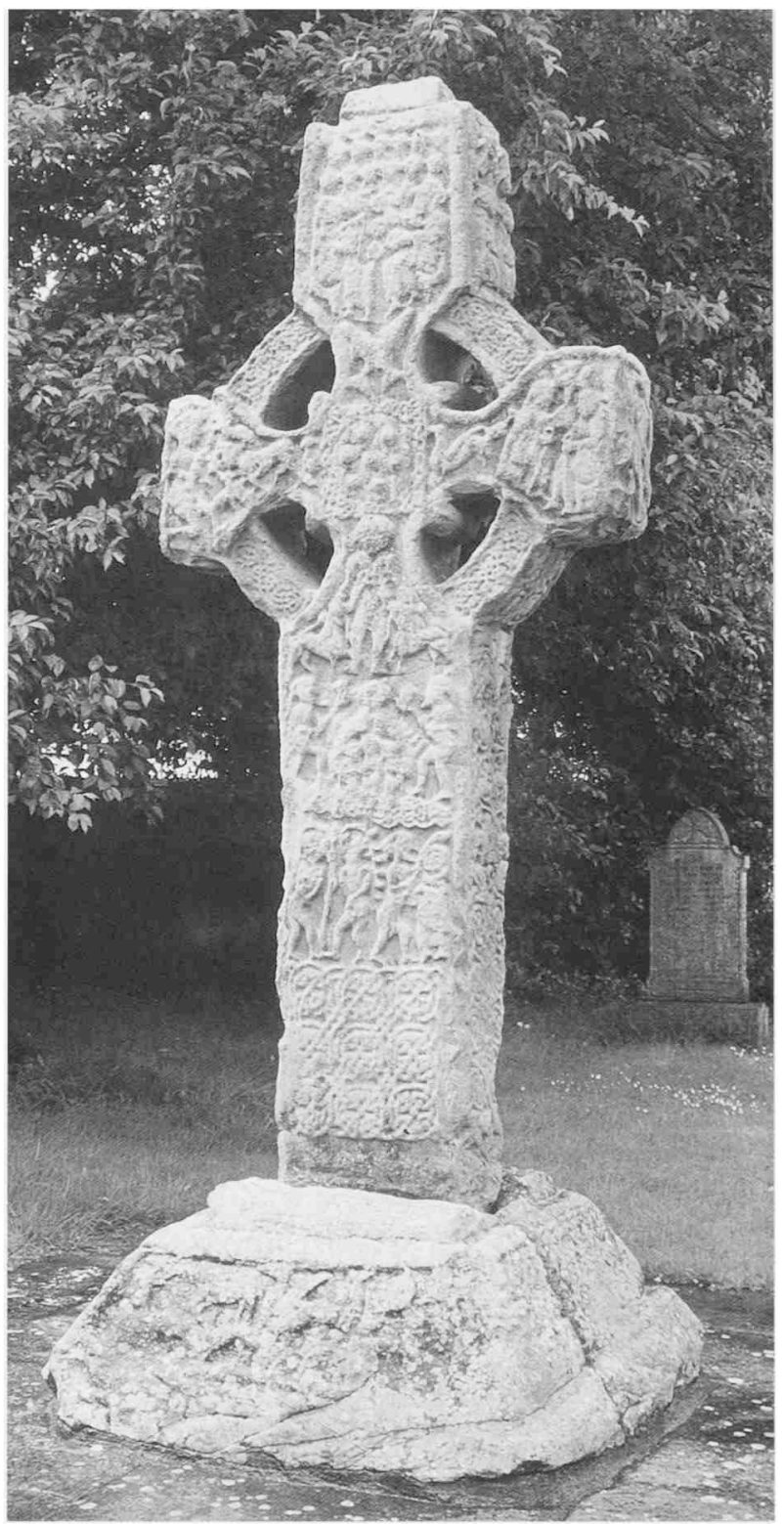

26. Krzyź św. Patryka i św. Kolumby z Kells (hr. Meath), strona wschodnia. Na bazie polowanie, na szczycie trzonu Daniel miedzy lwami, na zwieńczeniu w ksztalcie modelu kościoła, Dawid grający na harfie i Bóg Ojciec w otoczeniu apostołów. Według: P. Harbison, Irish High Crosses, 74. 


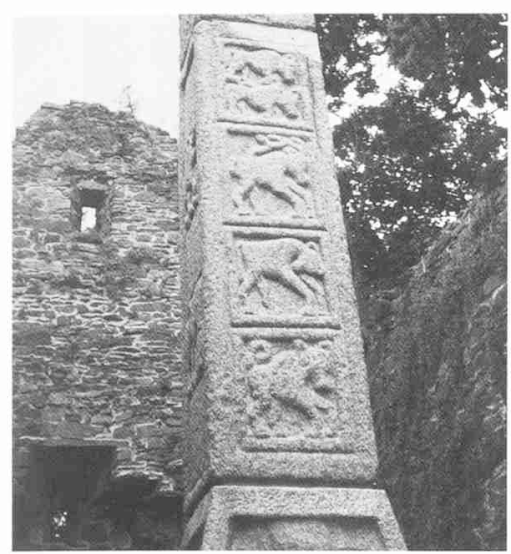

27a. Krzyż z Moone (hr. Kildare), strona zachodnia. Od dołu trzonu: pies, niedźwiedź, jeleń, woły, lew, romb, na skrzyżowaniu ramion spirala. Prywatne zbiory autorki

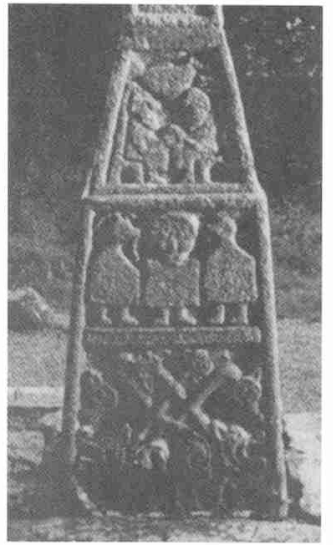

27b. Krzyż z Moone, strona północna. Na bazie zwierzęca plecionka, kuszenie św. Antoniego i kruk przynoszacy chleb św. Antoniemu i św. Pawłowi. Według: H. Richardson, J. Scarry, An Introduction, 133, Plate 167.

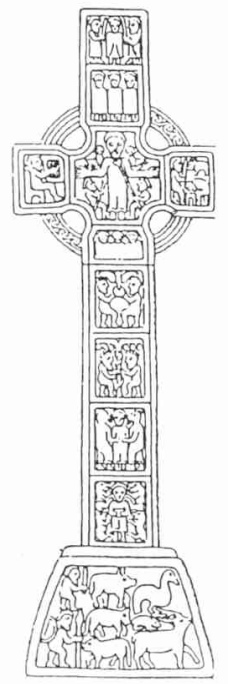

28. Krzyż Południowy z Casteldermot (hr. Kildare), strona zachodnia. Jest to krzyz szczególny, ponieważ posiada sceny biblijne jedynie na stronie zachodniej. Przedstawienia rozłożone zwykle na stronic wschodniej i zachodniej tu skumulowano na jednej z nich. Układ scen jest więc nietypowy i odbiega od zasygnalizowanych w artykule schematów. Pozostała jedynie scena polowania na bazie a na ramionach krzyża Dawid z harfą (lewa) i ofiara Abrahama (prawa). Według: H. Richardson - J. Scarry, An Introduction, 70, Plate 40. 


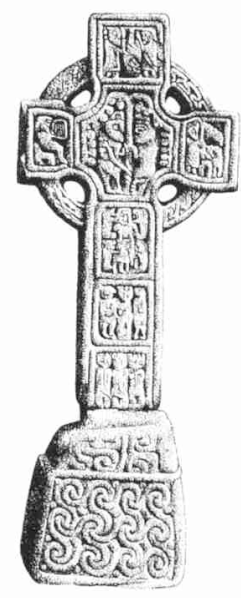

29a. Krzyż Północny z Casteldermot (hr. Kildare), strona zachodnia. Na szczycie trzonu Daniel między lwami, na ramionach krzyża Dawid $z$ harfa, Adam i Ewa, Ofiara Abrahama. Według. P. Harbison, Irish High Crosses, 29.

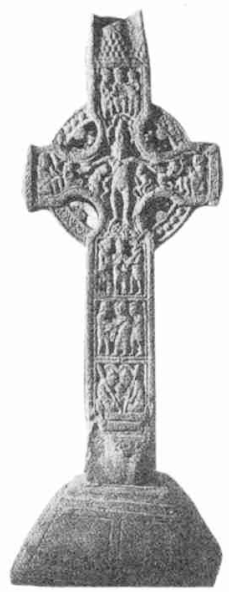

30. Krzyż z Durrow (hr. Offaly), strona zachodnia. Na skrzyżowaniu ramion

Ukrzyżowanie, ponizej: pojmanie lub Ecce Homo, pojmanie, złożenie Chrystusa do grobu.

Na szczacie model kościoła. Wedlug: $\mathrm{H}$. Richardson - J. Scarry, An Introduction, 92, Plate 96.

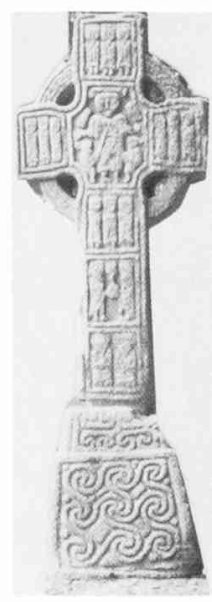

29b. Krzyż Północny z Casteldermot (hr. Kildare), strona wschodnia. Kwatera środkowa trzonu, kruk przynoszący chleb św. Antoniemu i św. Pawłowi. Prywatne zbiory autorki.

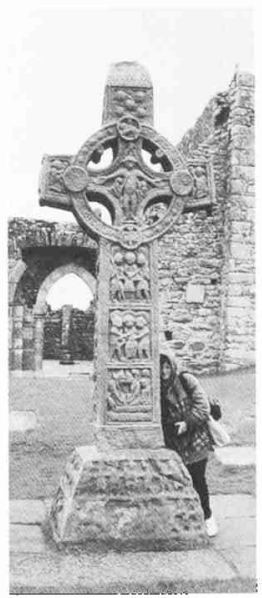

31. Krzyż Biblijny z Clonmacnois (hr. Offaly), strona zachodnia. Na bazie polowanie, na skrzyżowaniu ramion Ukrzyżowanie, poniżej: Ecce Homo, pojmanie, złożenie Chrystusa do grobu. $\mathrm{Na}$ szczycie model kościoła. Według: zbiory prywatne autorki. 


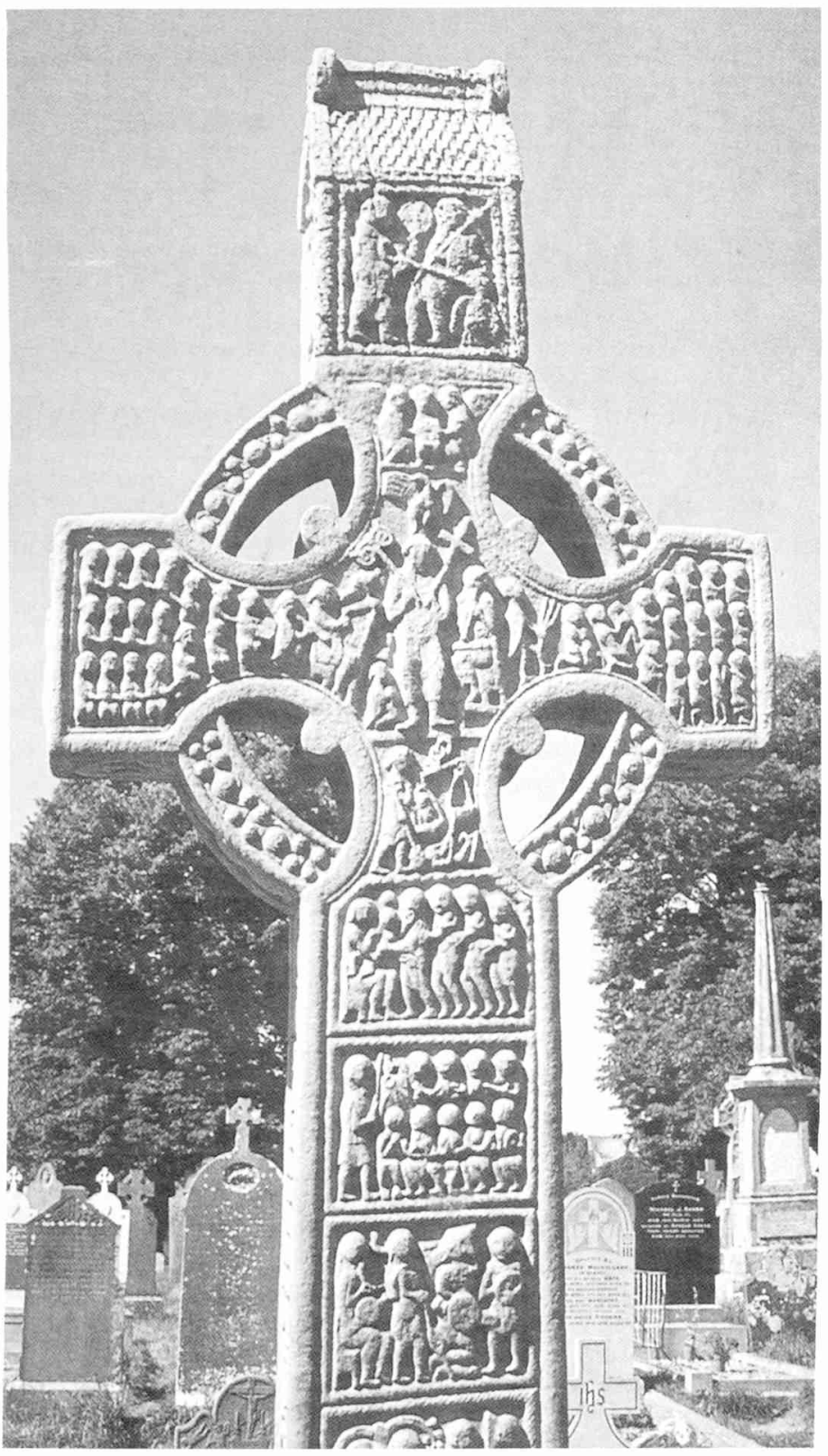

32. Krzyż Muiredacha z Monasterboice (hr. Louth), strona wschodnia. Na bazie polowanie, na skrzyżowaniu ramion scena paruzji, na lewo od Chrystusa Dawid grający na harfie. Na szczycie model kościoła. Wedlug: P. Harbison, Irish High Crosses, obwoluta. 


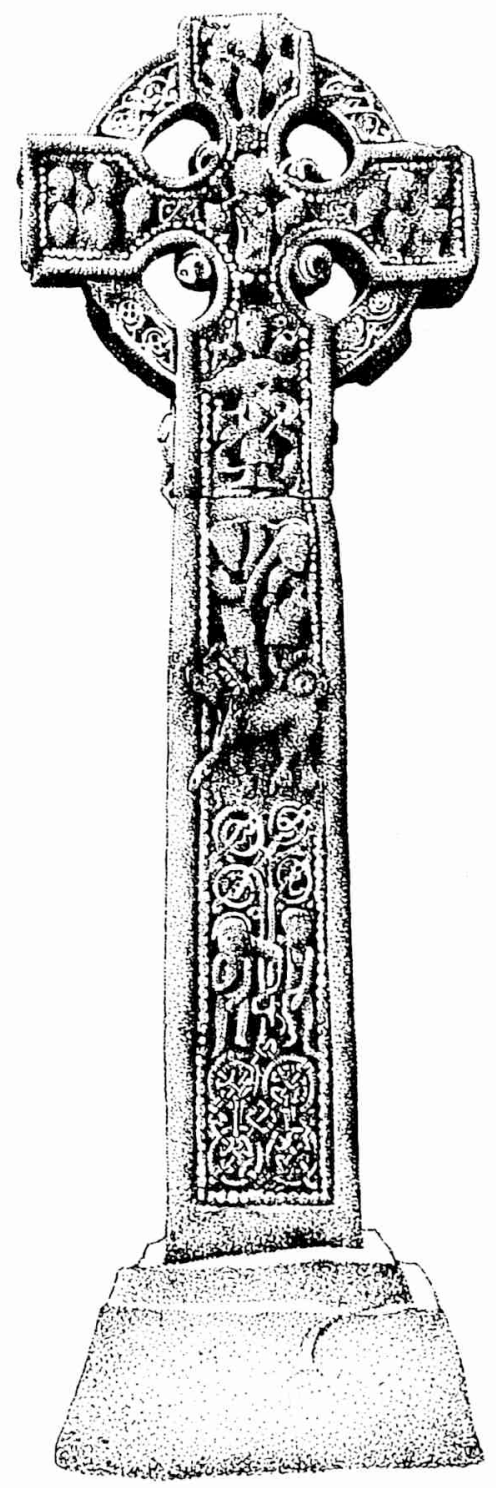

33. Krzyż z Drumcliff (hr. Sligo), strona wschodnia. W polowie trzonu figura lwa, na szczycie trzonu Daniel między lwami. Według: P. Harbison, Irish High Crosses, 51.

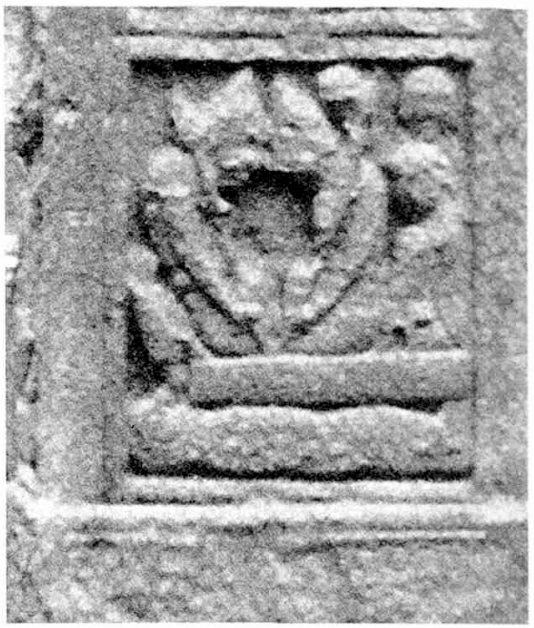

34. Zlozenie Chrystusa do grobu, fragment krzyża Biblijnego z Clonmacnois (hr. Offaly), strona zachodnia. Fragment il. 8.

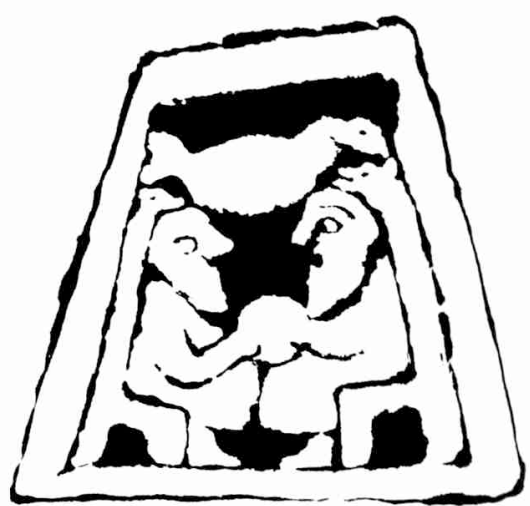

35. Przerys sceny z krzyża z Moone (hr. Kildare), kruk przynoszący chleb św. Antoniemu i św. Pawłowi. Według: B. Brand-Förster, Das irische Hochkreuz. Ursprung - Entwicklung - Gestalt, Stuttgart 1978, 87, fig. 27. 


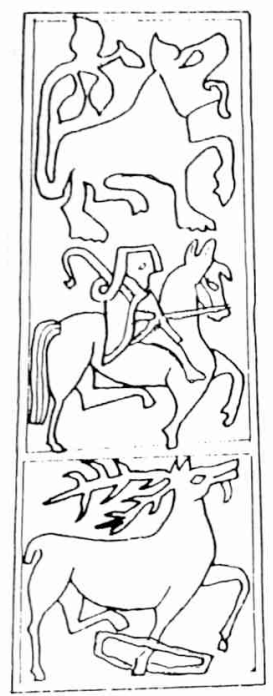

36a. Przerys fragmentu krzyża z Clonmacnois (hr. Offaly), jeleń, jeździec $\mathrm{i}$ lew. Według: C. Hicks, Animals in Early Medieval Art., Edinburgh 1993,175, fig. 3.29b.

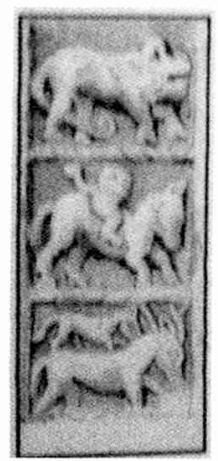

36b. Przerys fragmentu krzyża z Moone (hr. Kildare), jeleń, jeździec, lew.

Krzyż niedawno odkryty, niepublikowany, rekonstrukcja prezentowana in situ.

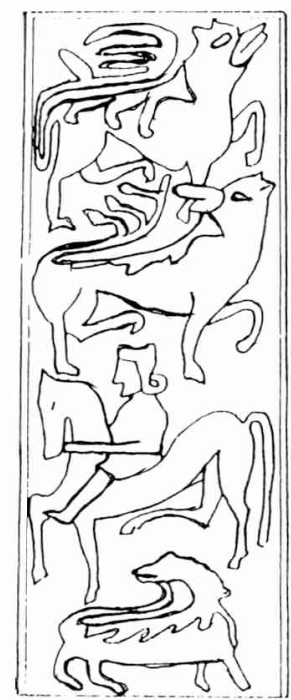

37. Przerys fragmentu krzyża z Clonmacnois (hr. Ofally), jeździcc i lwy. Według: C. Hicks, Animals in Early Medieval Art., Edinburgh 1993, 175, fig.3.29c. 

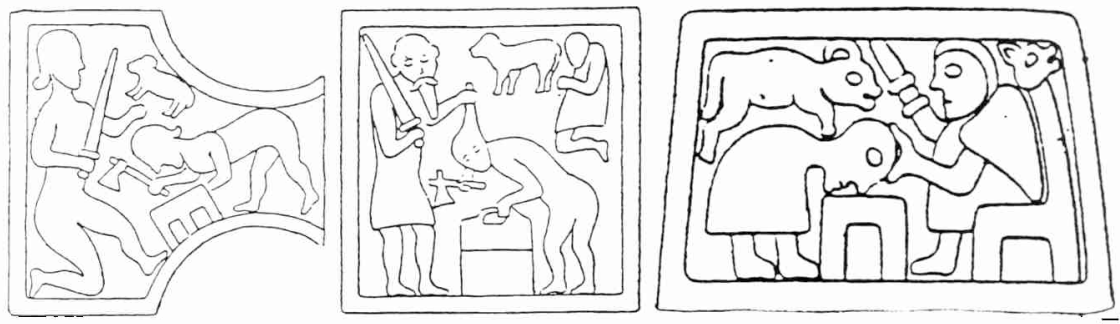

38a-c. Przerys sceny Ofiara Abrahama na krzyżach: a. św. Patryka i św. Kolumby z Kells, b. Krzyż Wysoki z Monasterboice, c. Krzyż z Moone. Według: J. Romilly Allen, Early Cbristian

Symbolism in Great Britain and Ireland, Londyn 1887, repr. 1992, 211, fig. 66, 218, fig. 70.

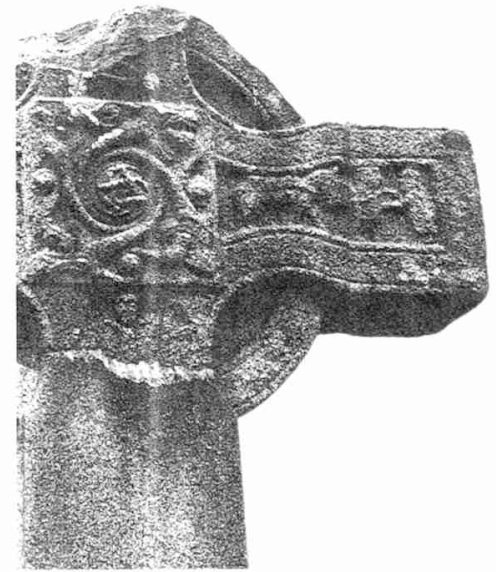

39. Krzyzz z Dromiskin (hr. Louth), na lewym (niewidocznym) ramieniu polowanic na jelenia, w centrum spirala, na prawym ramieniu pochód z relikwiami. Według: $H$. Richardson - J. Scarry, An Introduction, 102, Plate 104.

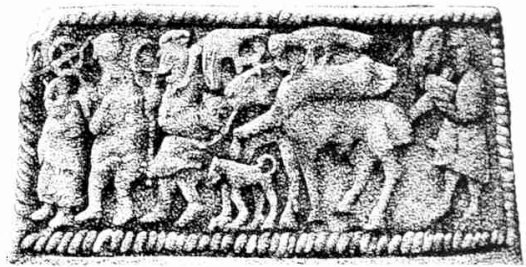

40. Przerys bazy krzyża Północnego z Ahenny (hr. Tipperary). Scena pochodzi wprawdzie $z$ bazy ale jest niemal kopią omawianego typu przedstawienia na zwieńczeniach krzyży, interpretowanego przez badaczy jako korowód z relikwiami. Według: P. Harbison, Irish High Crosses, 16.

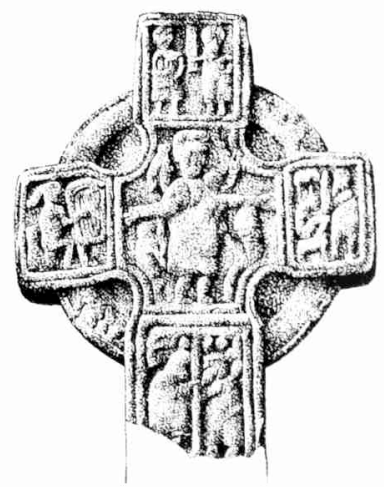

41. Krzyż Ullard (hr. Killkeny), u góty trzonu Adam i Ewa, na zwieńczeniu Dawid $z$ harfą, Ukrzyżowanie i Ofiara Abrahama. Wedlug: P. Harbison, Irish High Crosses, 108. 


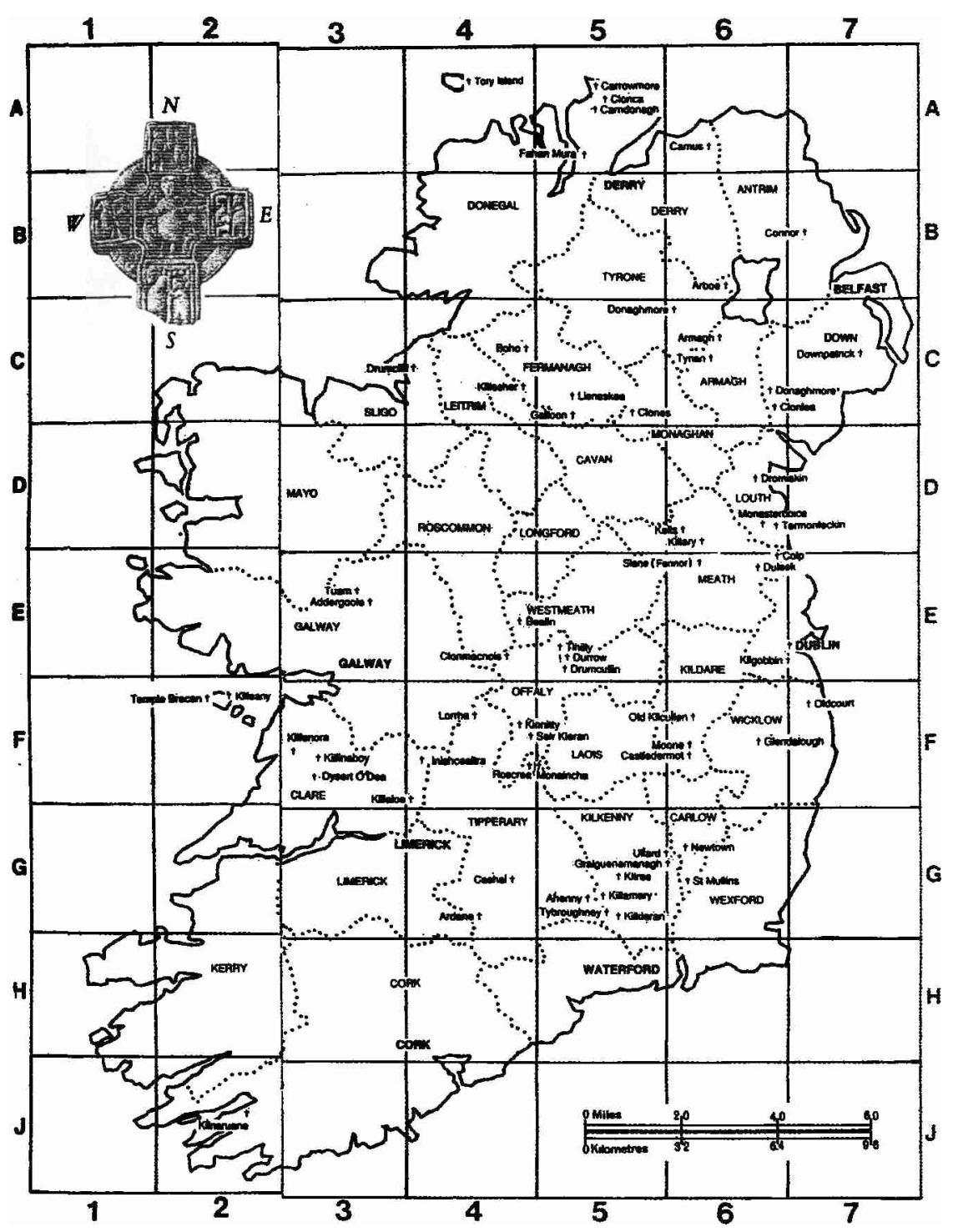

42. Mapa Irlandii z podzialem na hrabstwa i zaznaczeniem miejsc wy'stępowania najważniejszych krzyży, wedlug: P. Harbison, Irish High Crosses, 110-111. 


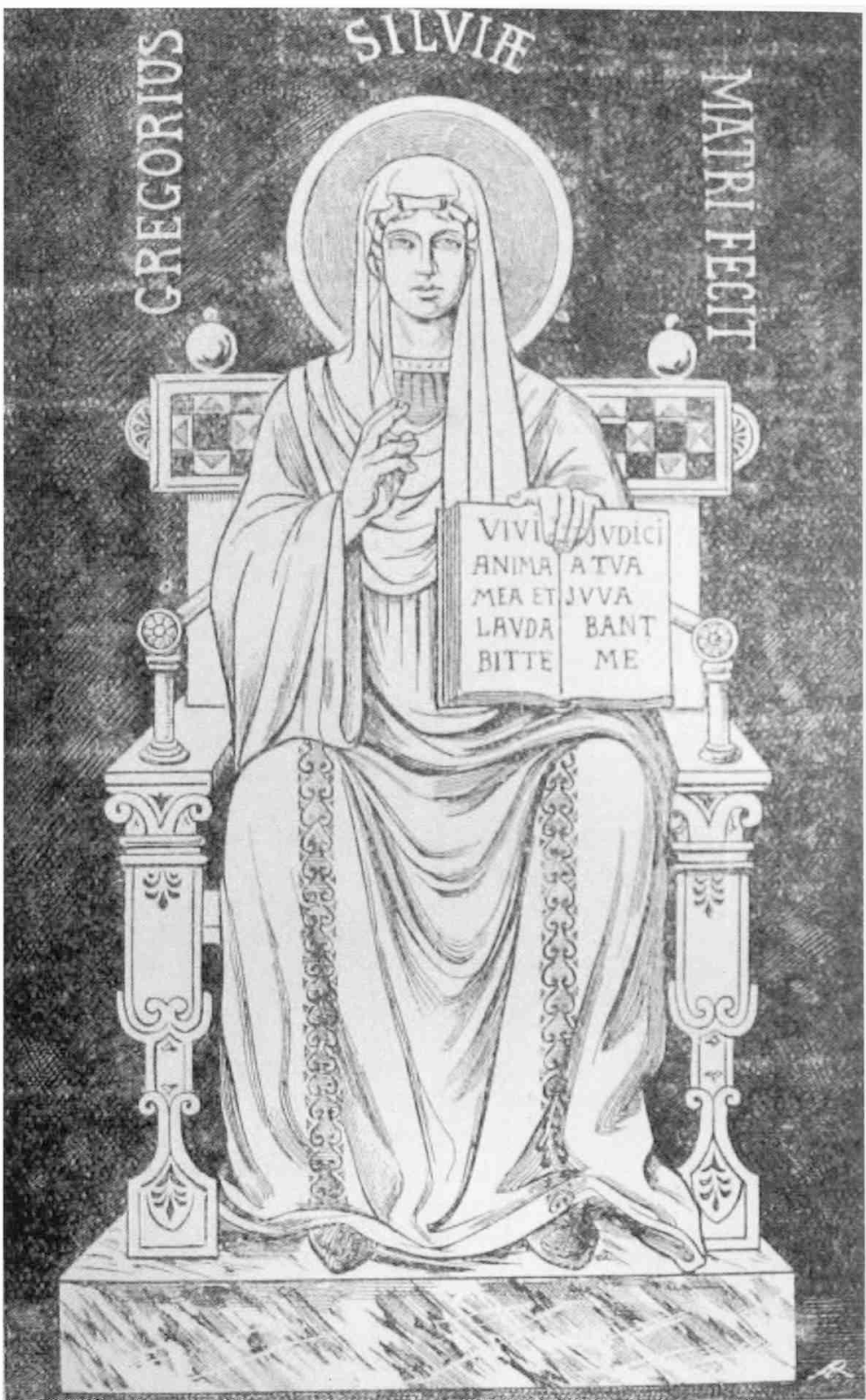

43. Obraz Sylwii w opisic Jana Diakona (IV 83); Rekonstrukcja E. Wuescher-Becchi, DACL VI 2, 1766. 


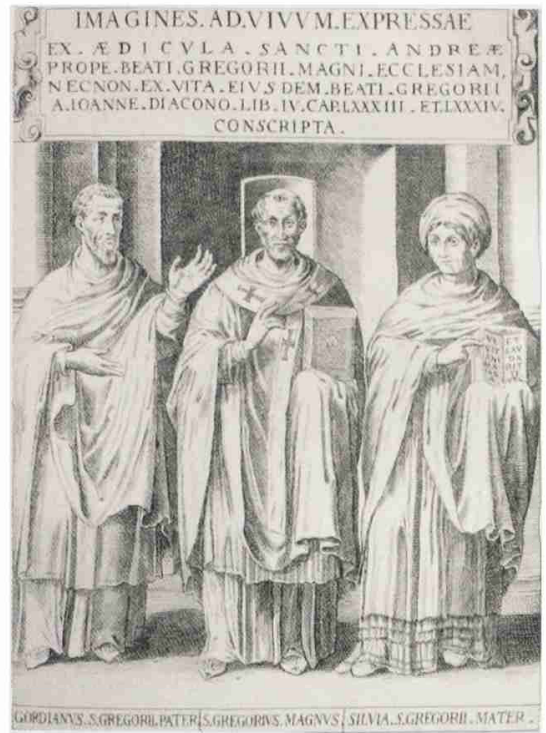

44. Obraz rodziców św. Grzegorza w kaplicy św. Sylwii w kościele św. Saby, będący wierną kopią rekonstrukcji A. Rocchi, DACL VI 2, 1762

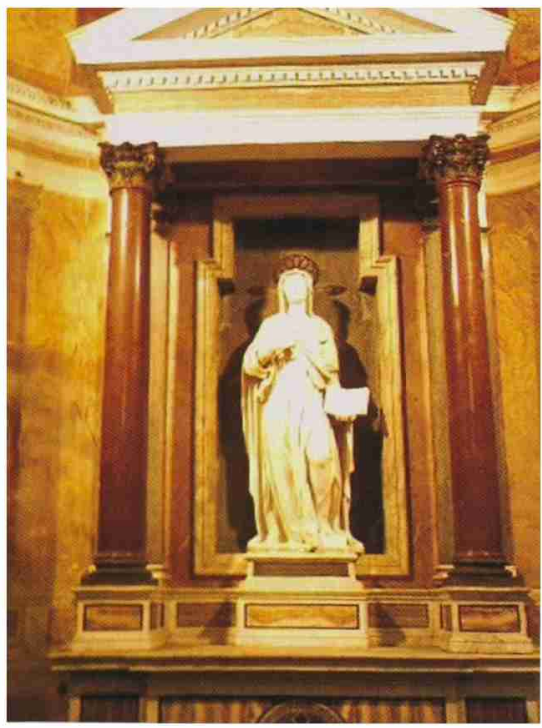

45. Statua Sylwii N. Corderiego w jej kaplicy na Monte Scauri. 


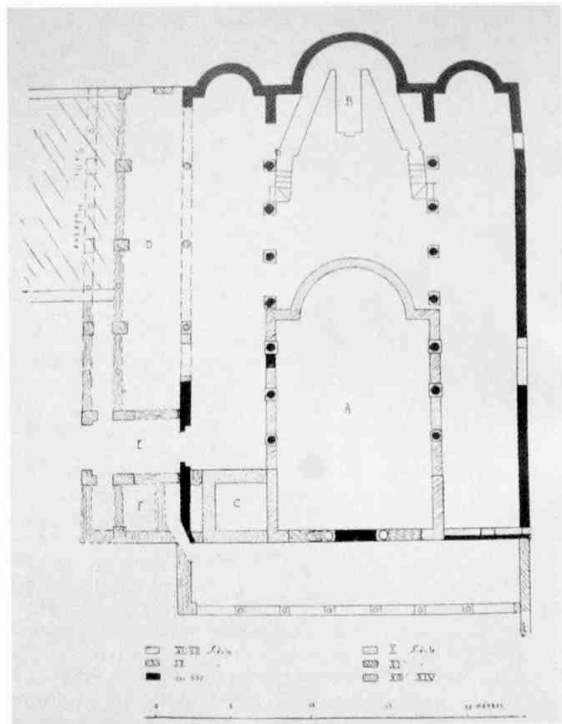

46. Plan kościoła św. Saby z podziemnym oratorium św. Sylwii (A).

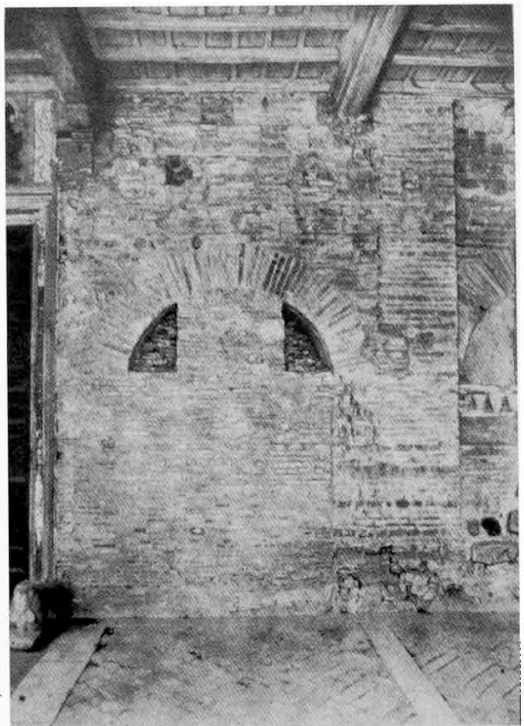

47. Resztki fasady oratorium św. Sylwii w podziemiach kościoła św. Saby wg J. Lestocquoy, s. 318. 


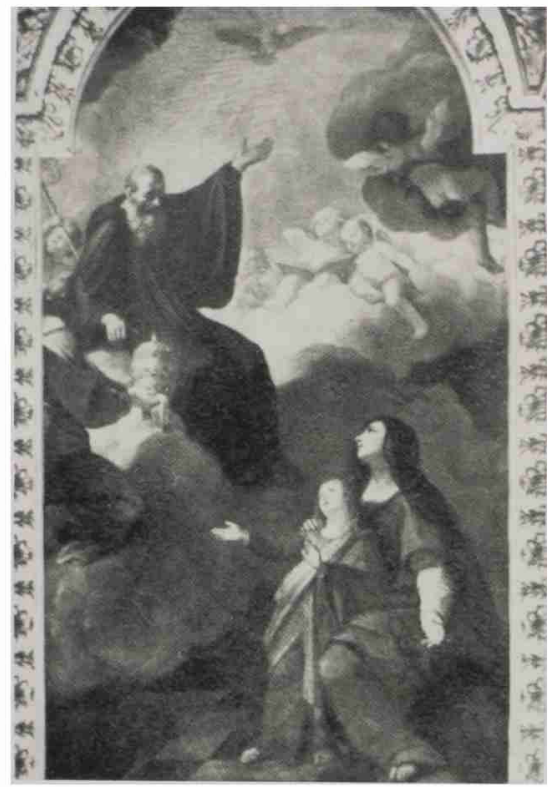

48. Obraz J. Parkera w ołtarzu kościoła św. Grzegorza w Rzymie, przedstawiający Sylwię ofiarującą małego Grzegorza św. Benedyktowi.

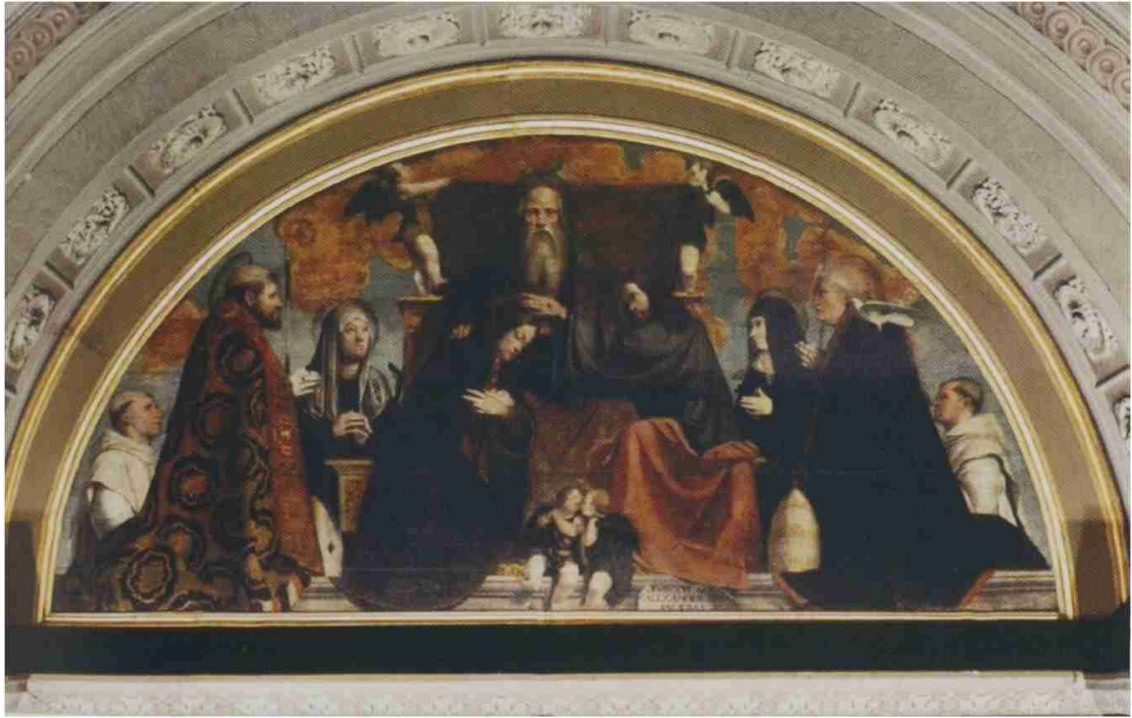

49. Koronacja NMP A. Moretta w kościele św. Jana Ewangelisty w Brescii, z klęczącymi po lewej stronie - Augustynem i Moniką, po prawej - Grzegorzem i Sylwią 


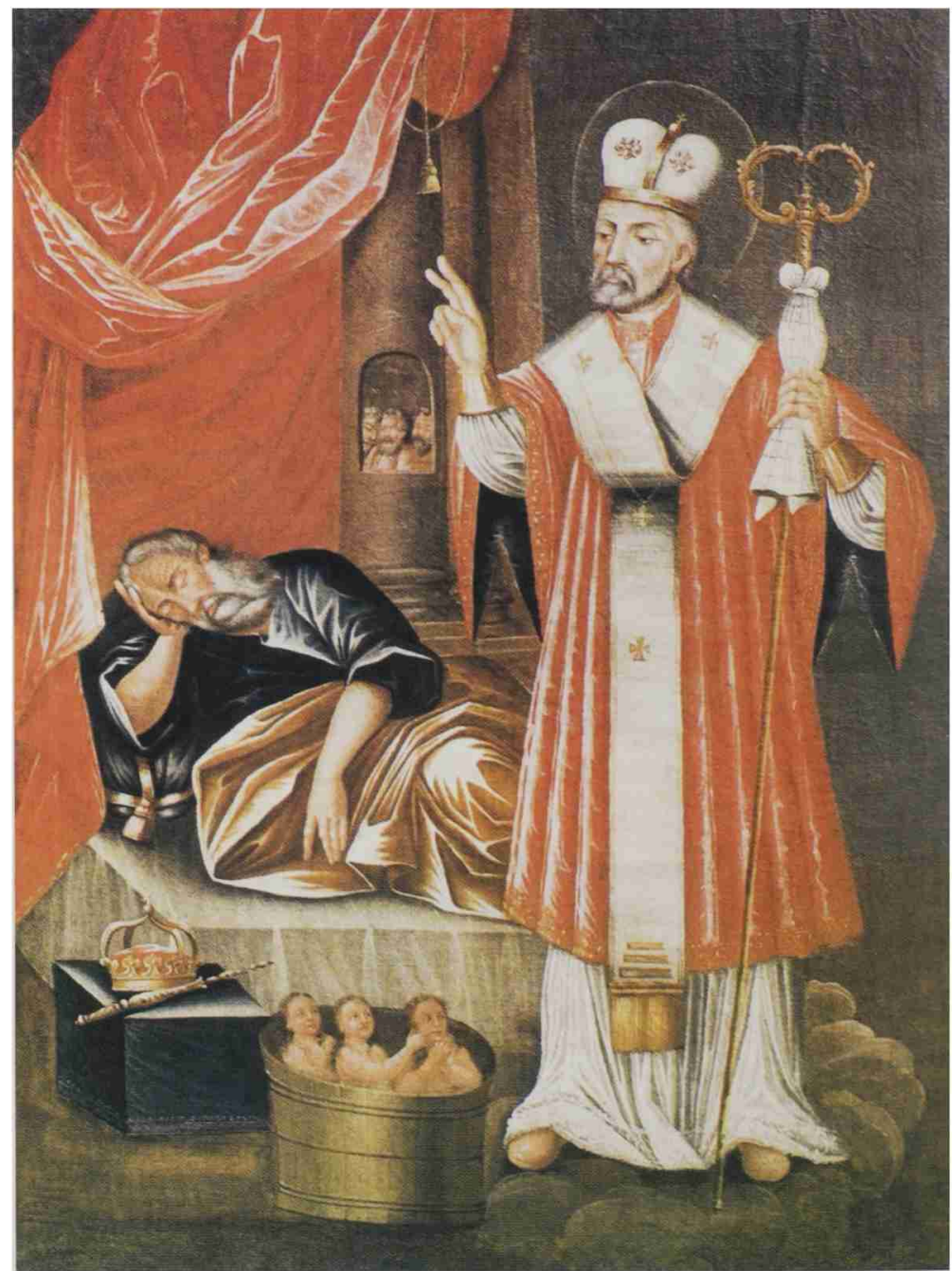

50. Obraz św. Mikołaja Cudotwórcy z kościola pw. Podwyższenia Krzyża Świętego w Opolu Podedwórzu 


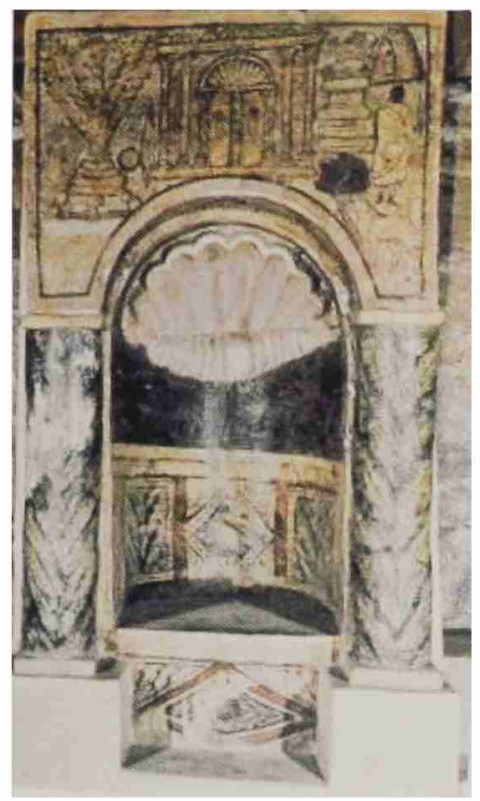

51. Nisza pomieszczenia na Torę z malowidłem wyobrazającym akedah na zachodniej ścianie synagogi w Dura Europos.

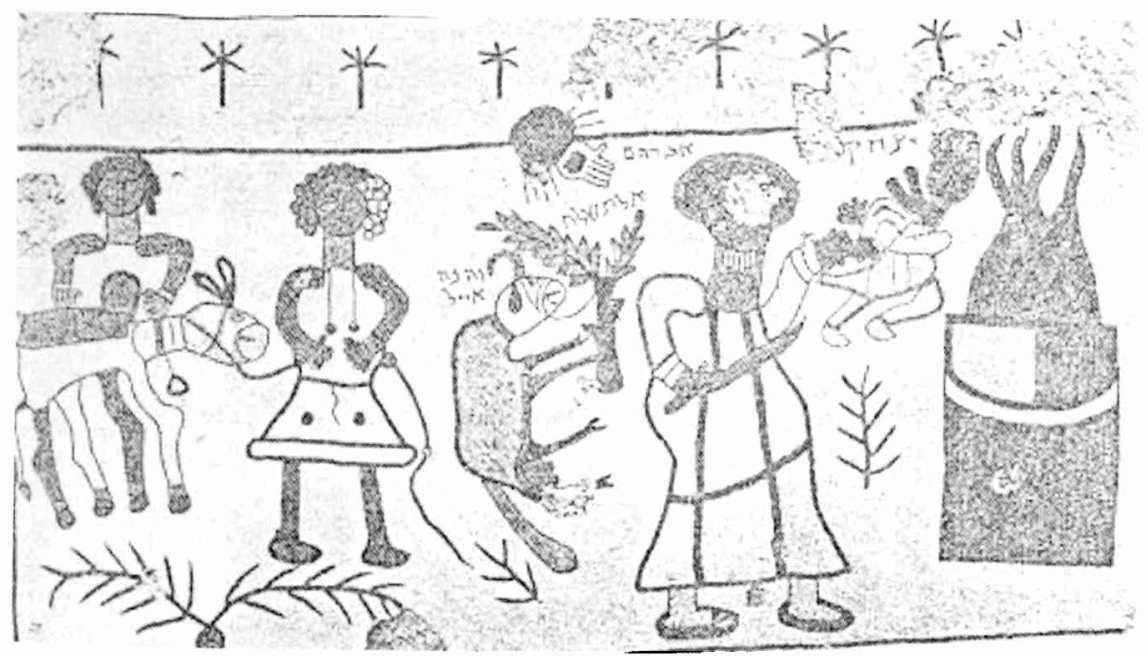

52. Scena akedah na mozaice synagogi w Beth Alfa. 


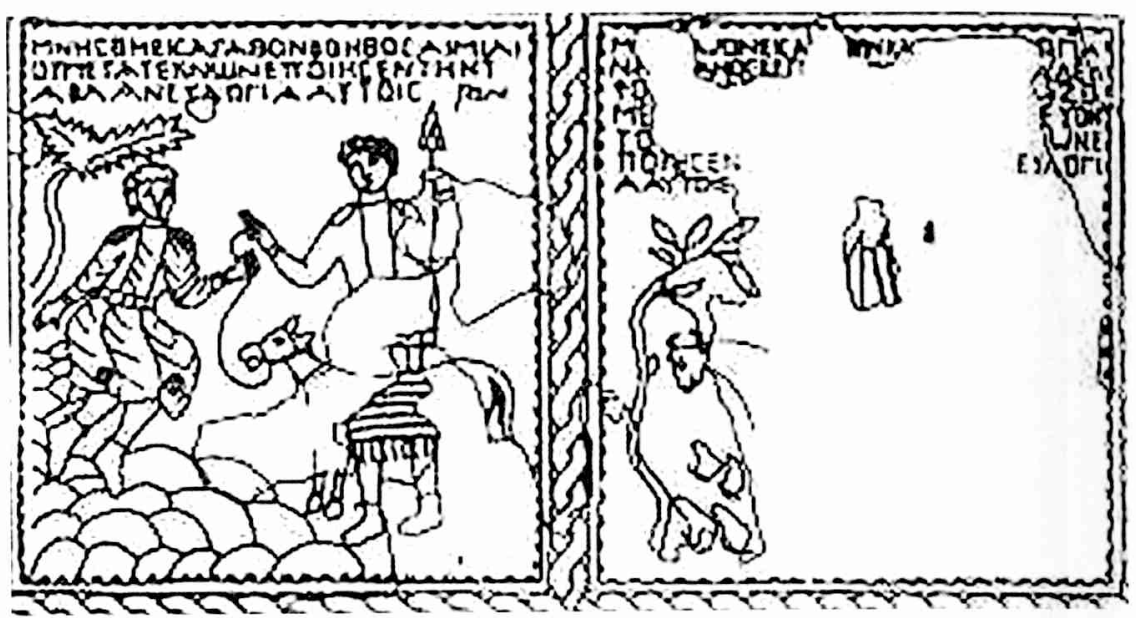

53. Panele mozaiki z Seforis przedstawiające historię ofiary Abrahama.

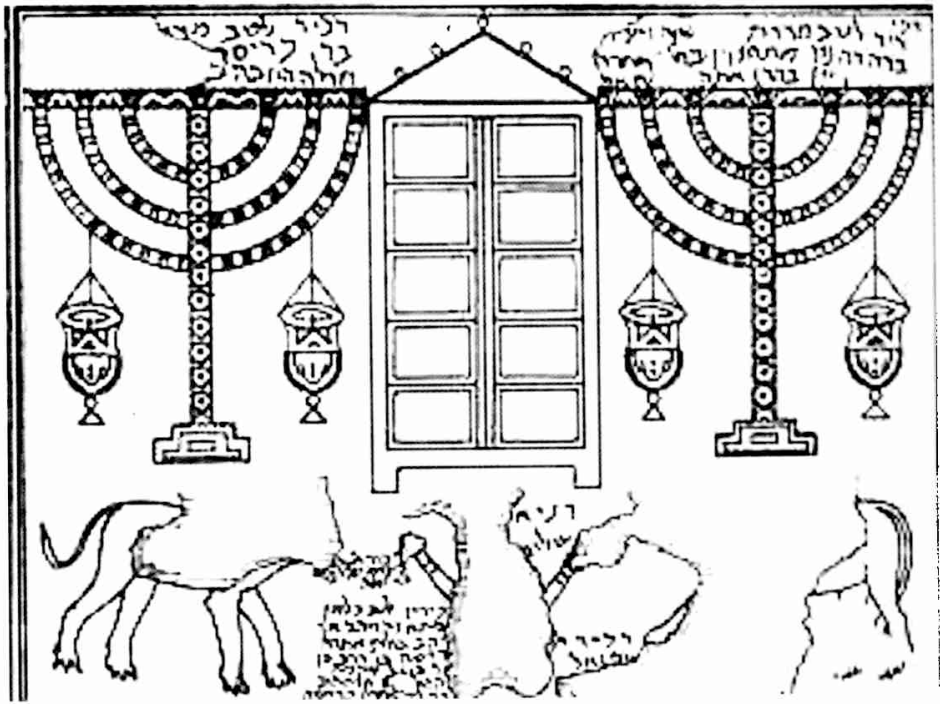

54. Scena Daniela wśród lwów na mozaice $\mathrm{z} \mathrm{Na}^{\prime}$ aran 


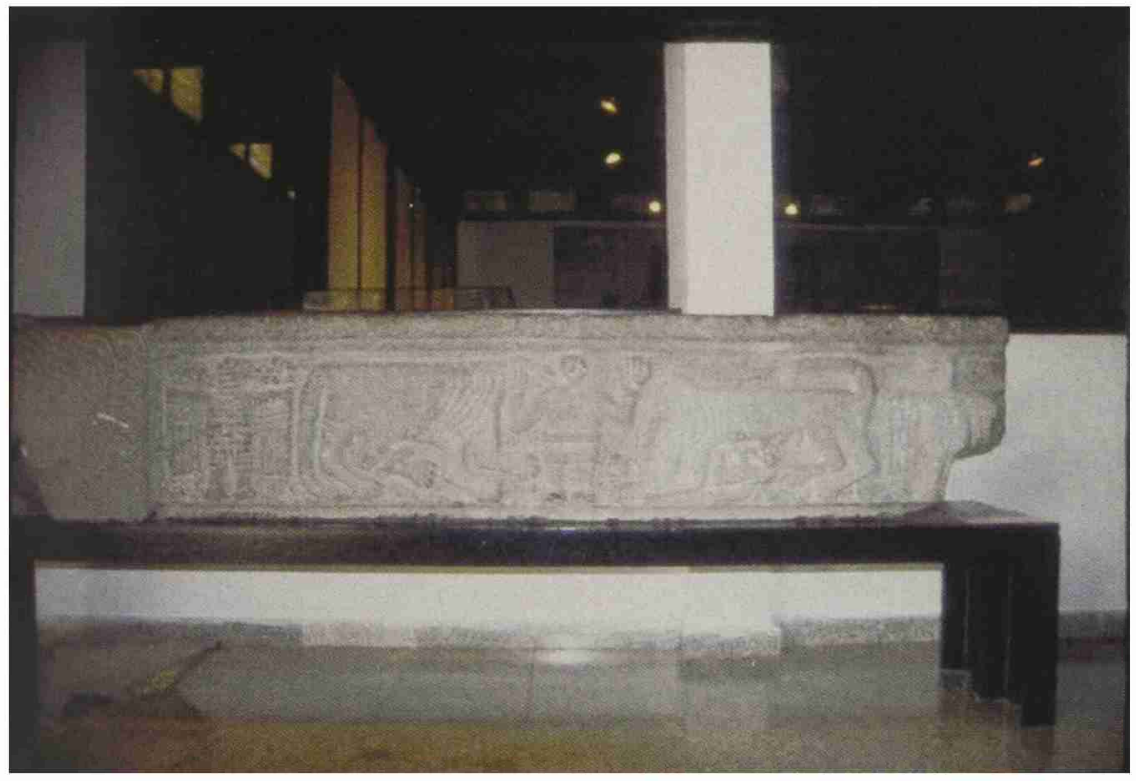

55. Relief ortostatu z En Samsam w Golanie ze sceną Daniela w jaskini lwów.

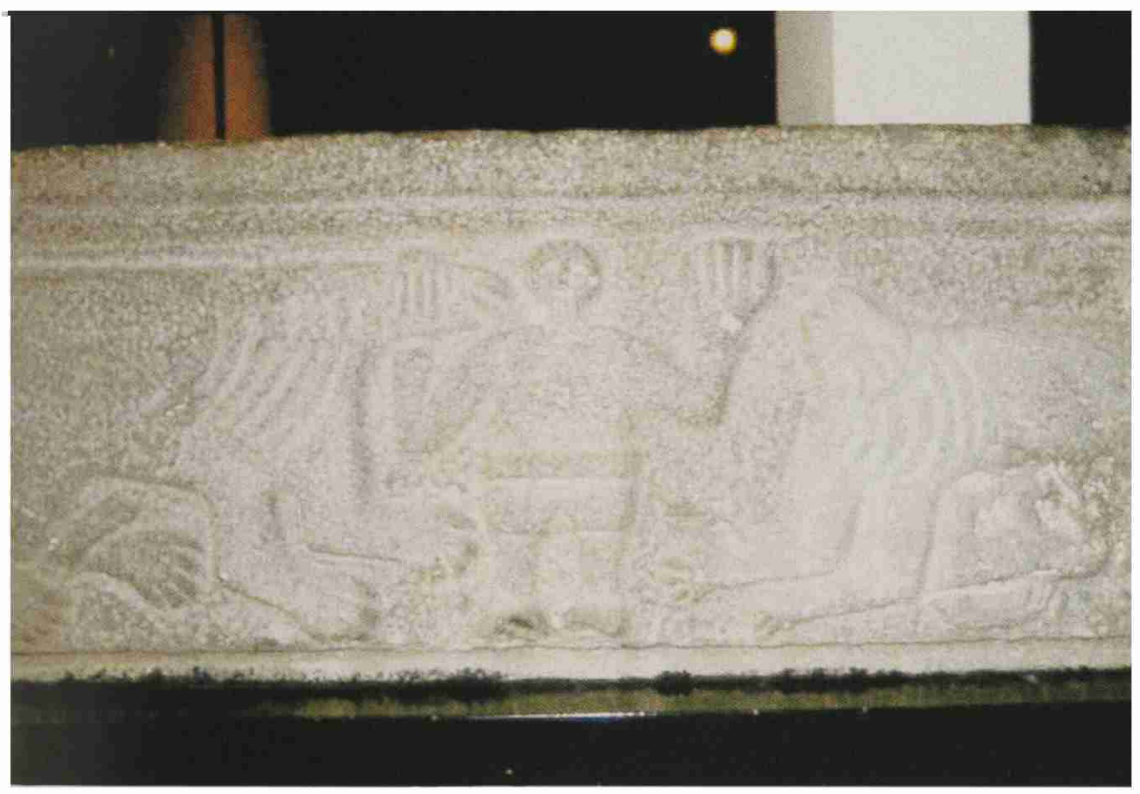

56. Środkowa część reliefu z prorokiem Danielem z En Samsam w Golanie. 


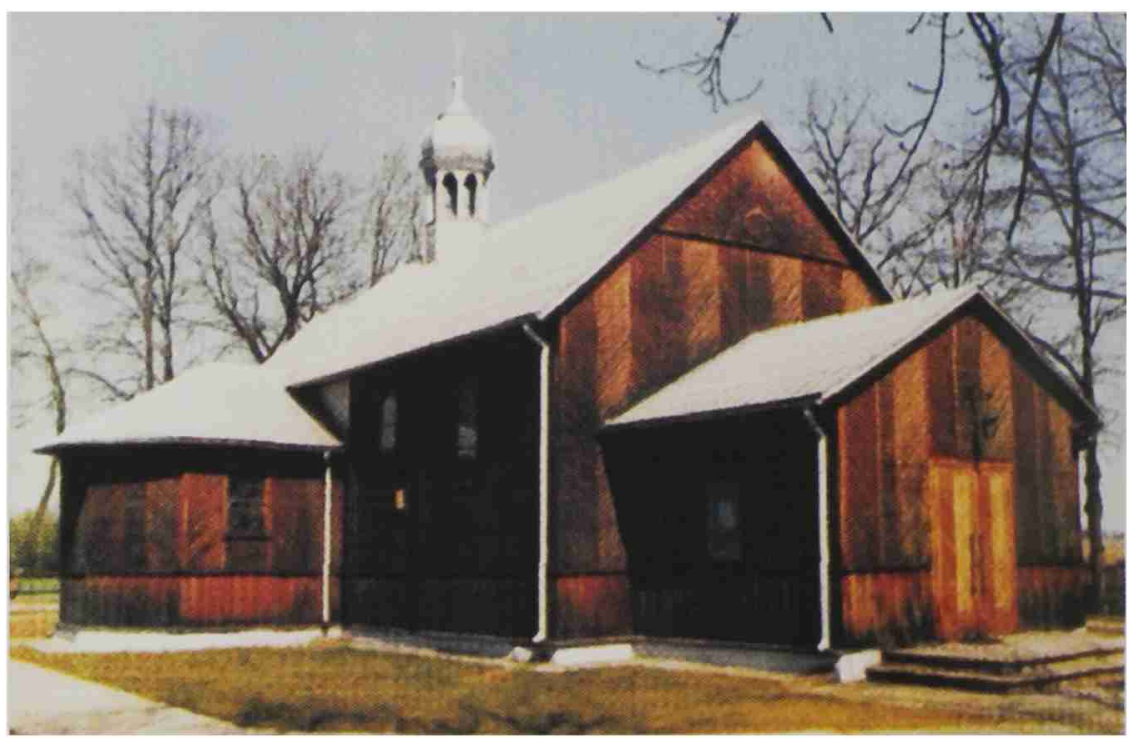

57

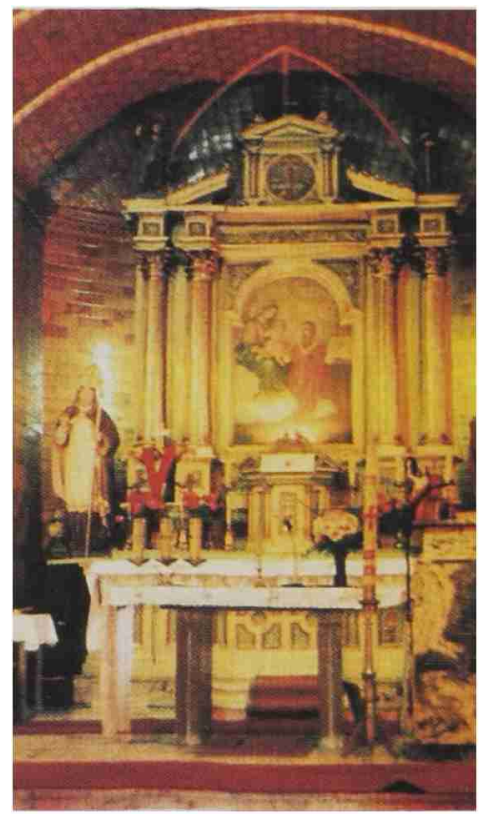

58

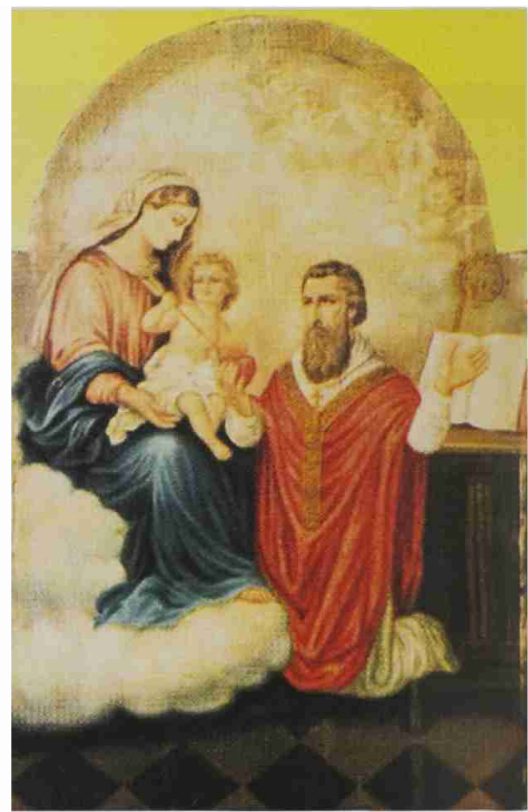

59

Kościół św. Augustyna w Jamach Wielkich 

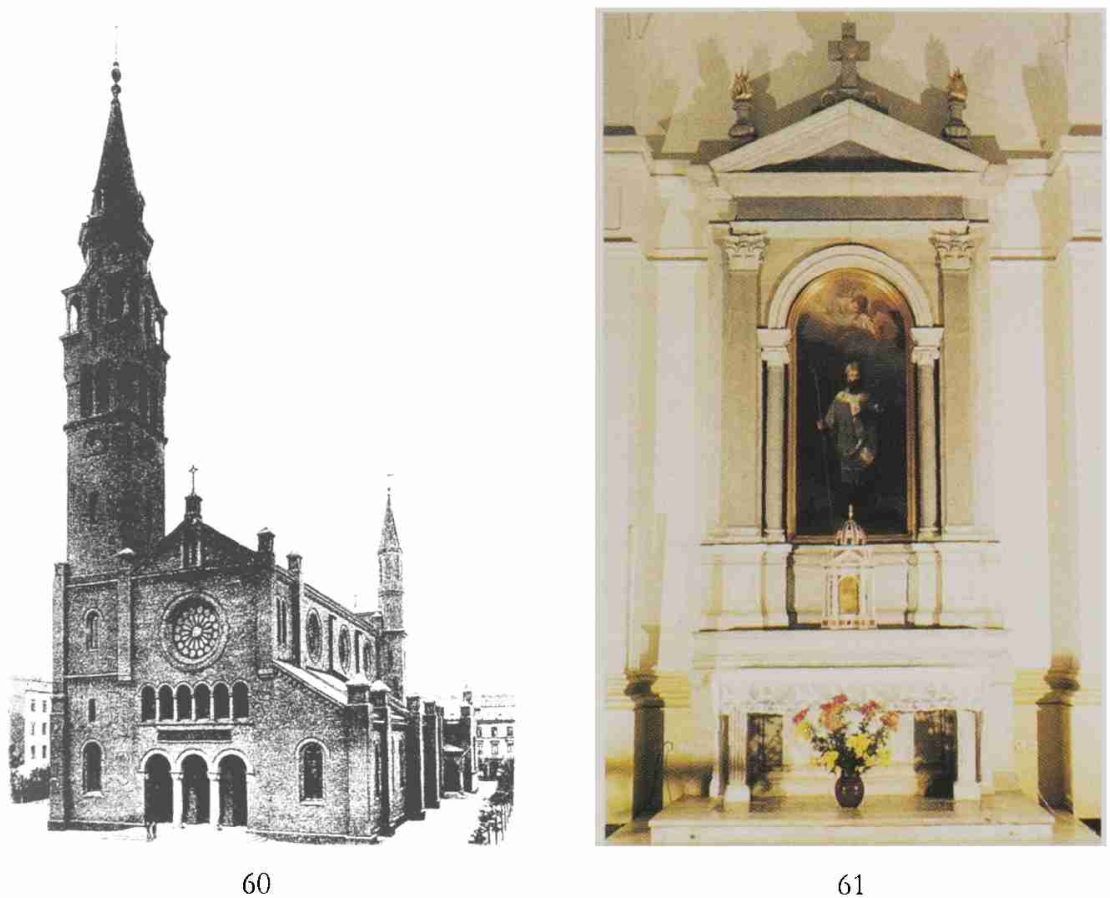

61

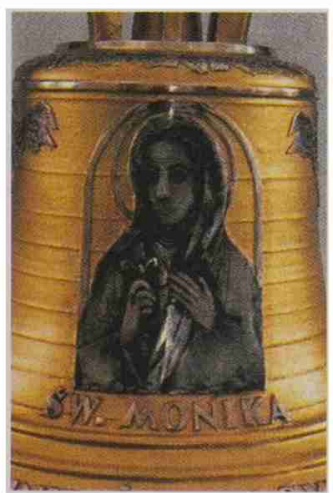

62

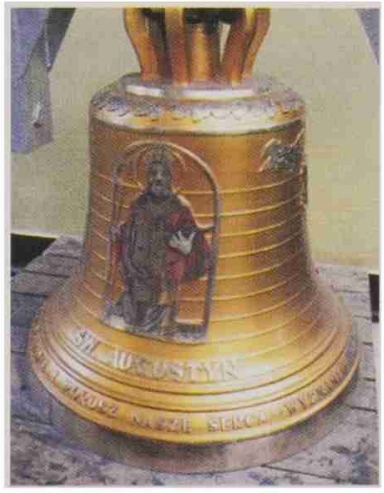

63

Kościól św. Augustyna w Warszawie-Muranowie na Nowolipkach 



\section{ANEKS}

\section{PIEŚNI O ŚW. AUGUSTYNIE}

\section{A. Jamy Wielkie}

1. Wielki Biskupie, Kościoła doktorze, $\mathrm{z}$ podziwem wielbim Twej świętości blask. Ufni w Twą pomoc blagamy w pokorze, uproś czcicielom zdrój potrzebnych lask.

Ref.: Niechaj Twe imię pośród nas zasłynie. Módl się za nami święty Augustynie.

2. Wpatrzeni w Ciebie, w Twe życia koleje, jako Cię zwołal z błędnej drogi Bóg. W Tobie Patronie składamy nadzieję, Ty nam pokażesz ślady Twoich dróg.

Ref.: Że w burzy życia nikt $\mathrm{z}$ nas nie zaginie. Módl się za nami święty Augustynie.

\section{B. Warszawa-Muranów na Nowolipkach}

1. Wiele dróg w życiu przeszedłeś, a jedna pokój przyniosła gdyś zrzucił grzechu niewolę i śpiewal Bogu przez łzy:

Ref. Tak późno poznalem Ciebie, o Panie miłości moja! Serce me niespokojne niech w Tobie spocznie już! (2x)

2. Jak się przyoblec w Chrystusa i zacząć wszystko na nowo; zrozumieć sens tego życia by wyznać Bogu jak Ty:

Ref. Tak późno poznalem Ciebie...

3. Prostą nam dajesz odpowiedź patronie trudnych powrotów, o Augustynie pobożny, daj nam się wsłuchać w Twój głos:

Ref. Tak późno poznałem Ciebie... 
Wyznawca Pański, którego narody

Wielbią po świecie pobożnymi glosy

W dniu tym szczęśliwy dostąpił nagrody,

Wzięty w niebiosy.

Mądry pobożny, pokorny i skromny,

Bez żadnej skazy pędzil żywot $z$ chwałą,

Póki zasilał dech zycia przytomny,

śmiertelne cialo.

Dlatego społem slawimy hymnami,

Cudne wawrzyny i blask sławy Jego,

Aby nas wspierał świętymi modłami,

Czasu każdego.

III

Ref. Niespokojne jest serce moje,

Dopóki w Tobie nie spocznie.

Za późno Cię pokochalem, o Piękności tak dawna,

A jednak zawsze tak nowa, za późno Cię pokochałem.

A oto byłeś we mnie, w moim wnętrzu, ja na zewnątrz Cię szukałem Do mnóstwa pięknych rzeczy się garnąłem, które przecież

Ty stworzyłeś 